مقدمه: هلف اصلى ثُوهش بيشرو، برزسى رابطه اجتماعات با رفاه

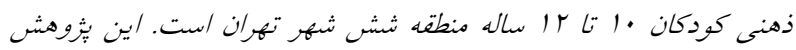

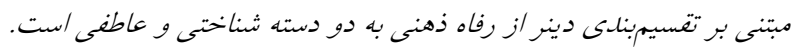

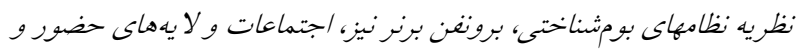

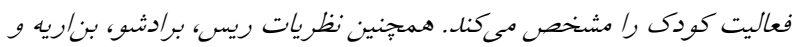

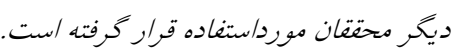

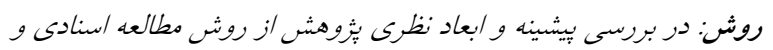

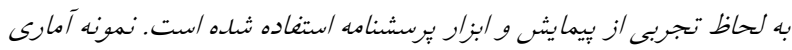
الr

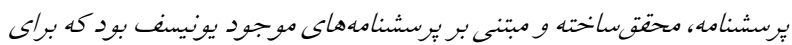

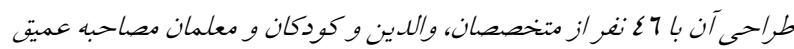

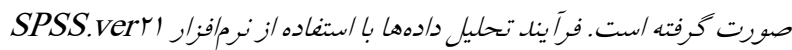
و روشهاى آمار توصينى (فراوانى و درصد فراوانى) و استنباطى (آزمون

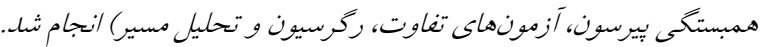

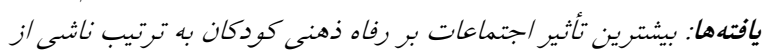

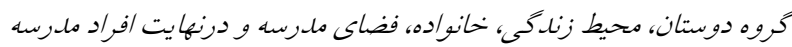

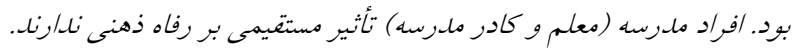

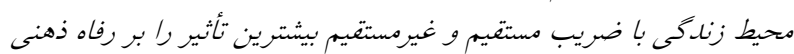

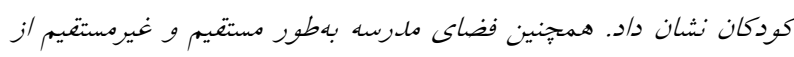

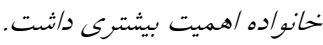

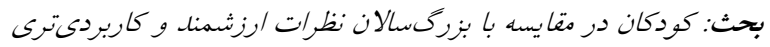

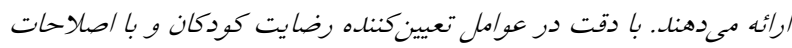

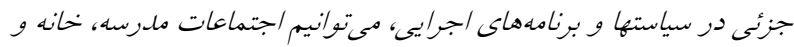

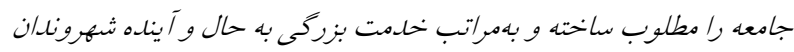
كوخى و كشورها داثته باشيم.
(다.

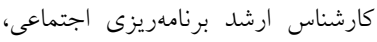
دانشكده علوم اجتماعى، دانشخاه تهران، تهران، ايران،

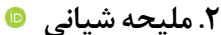

دكتر برنامهريزى اجتماعى، دانشي انشكده علوم

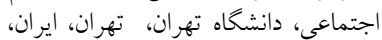
(نويسنده مسئول)،

$<$ msh_45@yahoo.com>

واثههایى كليدى:

اجتماعات، رفاه اجتماعى، رفاه ذهنى، كودكان

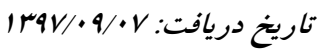
تاريخ بذيرث: 


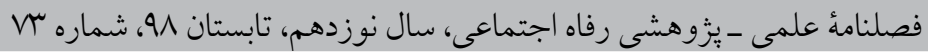

Social Welfare Quarterly, Vol 19, Summer 2019, No 73

\section{The Relationship between Communities and Sub- jective Well-Being of Children Aged 10 to 12 Years in the Sixth District of Tehran}

1- Salime Salehi Shahraki M.A. in Social Planning, Faculty of Social Sciences, Tehran University, Tehran, Iran

2- Malihe Shiani () Ph.D. in Social Planning, Tehran University, Faculty of Social Science, Tehran, Iran, (Corresponding Author)

$<$ msh_45@yahoo.com>

Keywords:

Communities, Social welfare, Subjective well-being, Children, Sixth district of Tehran

Received: $2018-12-08$

Accepted: 2019-7-17

\section{Short Abstract}

This Research is based on the Diner's approaches dividing the effective factors on subjective well-being as well as the theory of ecological systems of Bruffen Brener (1995) identifying the communities and layers of the child's presence and activities. The study of the background of the research was conducted using documentary study method and empirically using the scroll. The tool was a questionnaire which was distributed among 453 participants whose age range was 10-12 years old. The analysis process was performed using SPSS 21 software, descriptive statistics, and analytical methods. As indicated by the findings, school teachers are unlikely to have a direct impact on subjective well-being in multivariate regression. However, the school's environment appears to be important. The living environment with a direct and indirect coefficient of 0.48 has the greatest impact on the subjective well-being of children. Therefore, the most influential factors seem to be the living environment, the group of friends, and the school space, and ultimately, it is the family which affects the subjective well-being of children. Accordingly, it can be said that children have valuable and more useful, and careful consideration in the determinants of child satisfaction, with minor reforms in policies, has made the communities offer a great service to the future of the citizens and the countries. 


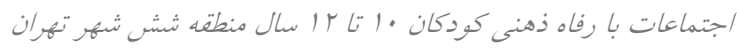

The Relationship between Communities and Subjective Well-Being of Children ...

\section{Extended Abstract}

Introduction: Children are usually ignored in the society while they are not able to express their ideas or try to know their own rights and show that they are not dependent on their families, adults, society, local, national or even international policies. Although areas such as education and hygiene have obvious and direct effects on children but it has been shown that child's living environment, school, people, and those who are around him/her influence the life and welfare of the child.

One the most important theories in intellectual welfare belongs to Diner (Edward Diener, Lucas, \& Oishi, 2002). Diner (Edward Diener et al., 2002) divides intellectual welfare into two aspects: emotional (positive feelings, negative feelings, and happiness) and cognitive (life satisfaction, district satisfaction, and quality of life) in order to know the concept. In this division, positive feelings include moods such as pleasure and satisfaction, reflection of people's desirability regarding one's life and negative feelings can be interpreted as dissatisfaction such as people's negative reflection towards life, health, events, and their interpretation (Ali tane, 2012).

Along with studying the effects of child communities on intellectual welfare, more emphasis on child satisfaction towards life and considering communities' conditions is his/her viewpoint (self-reporting) which again will be evaluated regarding communities, such as families, schools, people in the schools, environments and friends and the probable impacts that they might have on children's satisfaction towards life.

Bronfen brenner - in his ecological system theory, he states that child growth is influenced by some layers in the environment. Accordingly, changes or contradictions in every layer can be transferred to other layers (Aghdasi, 2010). Families, peer groups, schools, workplaces, and bigger social systems are considered effective environment layers affecting different aspects of child growth in which family is the most effective, long-lasting as well as the nearest layer in environment (Bronfen brenner, 1979). This pattern divides social environment into four systems.

Microsystem includes family which consists of parents and children, all these members have cross impact on one another. The family function connects with variables related to its members and factors like age, personality, financial and job related conditions, levels of education, and parents' health conditions can be regarded as the effective ones. 


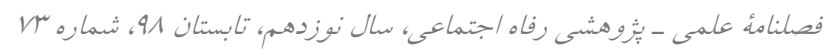

Social Welfare Quarterly, Vol 19, Summer 2019, No 73

Mesosystem: a small family system is influenced by mesosystem which surrounds it. It includes environments, such as extended family, neighbors, colleagues and friends.

Exosysteme: a mesosystem is influenced by exosysteme. This includes social environments, like social media, educational system, welfare, social, health, and support services.

Macro system: a macro system or the last layer refers to the views, beliefs, and hidden values in social organs in a society which are likely to have considerable impacts on family functions.

Following theoretical studies, effective communities, i.e. environment and the place of living, schools and teachers, houses and families, and friends are determined as places children spend most of their time; therefore they are regarded as the basis of research.

Method: In this research from among 12606 students in seond grade of public and private elementary schools of district 6453 of them were selected based on probability sampling as statistical sample which include 239 boys (\%52.8) and 214 girls (\%47.2). As regards children distribution we should state that there are 143 children at the age of $10(31.6 \%), 149$ children at the age of $11(32.9 \%)$ and 161 children at the age of 12 (35.5\%). 362 students (79.9\%) and 92 students (20.1\%) study in public and private schools respectively also 381 students $(84.1 \%)$ are from Tehran and 70 students (15.5\%) are from other cities in Iran.

Finding: Findings show there are no significant difference between intellectual welfare of boys with the mean of 86.54 and girls with mean of 86.75 . This is proved by $\mathrm{T}$ test with 2 independent samples. This test rejects any kind of difference in intellectual welfare with -0.195 and significant level of 0.84 .

The average scores of intellectual welfare of girls and boys show a small decrease from 10 years old (87.94) to 11 years old (87.31), then a significant decrease from 11 years old to 12 years old (84.87). This average for boys and girls has been the same during these years (except for 10 years old with 0.80 difference)

In the analysis of multivariate regression, the biggest effect resulted from friends groups, families, schools, and the place of living. School people (teachers and personnel) do not have direct impacts on intellectual welfare. The total impact in the place of living on intellectual welfare of children shows that it has a strong impact 
with direct and indirect coefficient of $48 \%$. Schools with direct and indirect coefficient of $33 \%$ have more significant impact than families. So the place of living has the biggest impact on children's welfare after friends, schools and families that were found to have more effects. High coefficient of families and friends show how important they are in developing the children's relationship with other groups. This means providing satisfactory relationships between childdren and different groups also affect intellectual aspects among children, at times it can also make up other defects. The indirect impact of environment on intellectual welfare is an interesting point which shows the significance of security and facilities discussion.

Discussion: In fact, children in this age enter a new stage in their lives in which they need a variety of facilities, such as sports, education and recreation. On the other hand, providing the environment and the possibility of using it, and participating in the programs are likely to be the main aspects.

This research proves that children can present valuable ideas and at times perfect and functional ones about adults' way of thinking. Paying deep attention to important factors of satisfaction and progress in children helps us make some changes in policies and executive programs to serve future citizens and the development of our country. These kinds of research studies, especially among children in Iran have not been conducted sufficiently. The necessity of a country development is considering financial capacities and intellectual welfare of the citizens in such a way that it can be felt in educational and executive organizations.

\section{Ethical Considerations}

\section{Funding}

In the present study, did not have any sponsors

\section{Authors' contributions}

All authors contributed in designing, running, and writing all parts of the research.

\section{Conflicts of interest}

This article does not conflict with other articles of my.

\section{Acknowledgments}

This article follows the principles of ethics and research and is endorsed by the Bu-Ali Sina University in this regard 


\section{مقامله}

بيش از ع درصد از جمعيت ايران را كودكان زير عا سال تشكيل مىدهند (مركز آمار ايران، 9011) و بهعنوان يك شهروند و بازيخر اجتماعى، بايد حقوقشان به رسميت

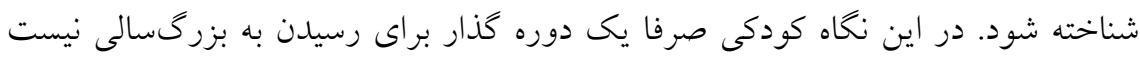

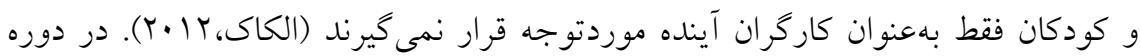

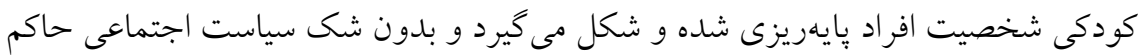

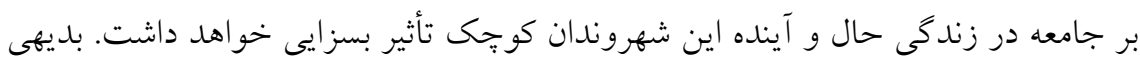
است كه وضعيت كودكان از هر دو سطح عينى و ذهنى رفاه متأثر است. رفاه ازجمله موضوعاتى است كه بيوسته بخش قابلتوجهى از انرزى، زمان و دغدغه

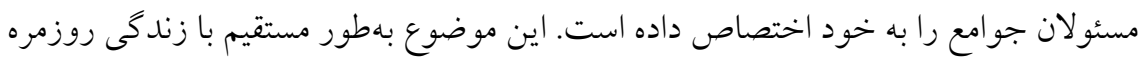

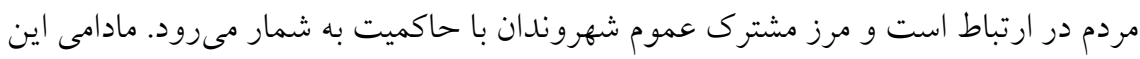
ارتباط باثبات مىماند كه هر دو بعد عينى و ذهنى رفاه مردم بر آورده شود.

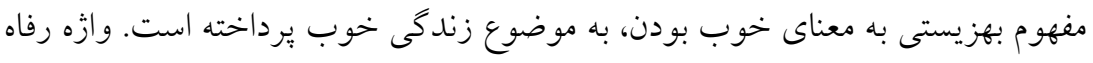

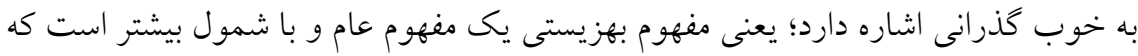

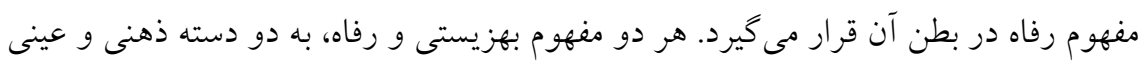

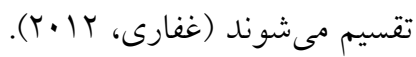

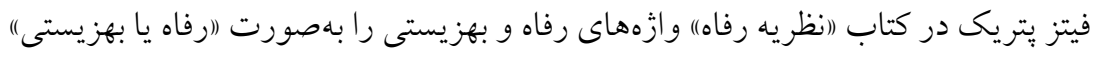

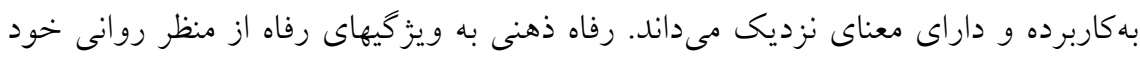

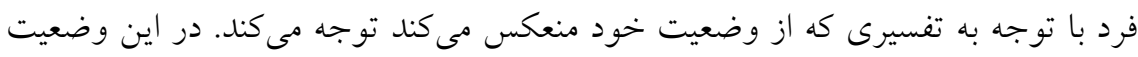

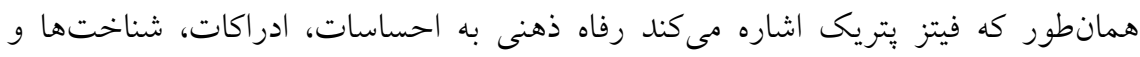

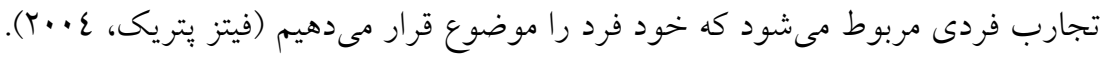


The Relationship between Communities and Subjective Well-Being of Children ...

رفاه عينى با احساسات، ادراك و تجربه فرد بىارتباط است. اما رفاه ذهنى به احساسات، شناختها و تجارب فردى مربوط مىشود كه موضوع رفاه قرارگرفته است. رفاه ذهنى ماهيت ذهنى دارد ولى درعينحال شاخصهاى عينى در برآورده كردن رفاه ذهنى اثر خذارند و زمانى اين اثر مشهود مىشود كه به امر ذهنى و معنايى بدل شود. آنجهه در اين مقاله به معناى رفاه ذهنى به كار مىرود، معادل وازه subjective well-being در متون انخليسى است. دليل تأكيد بر استفاده از معناى رفاه قرابت بيشتر با تعاريف حوزه علوم اجتماعى و بهويزه علم سياست گذارى اجتماعى است. در ادبيات اين موضوع اصطلاح بهزيستى اغلب بهجاى رفاه ذهنى استفاده مىشود، زيرا از هر مفهوم قراردادى يا ناشناخته در مورد شموليت اين مفهوم اجتناب مى كند (دينر،

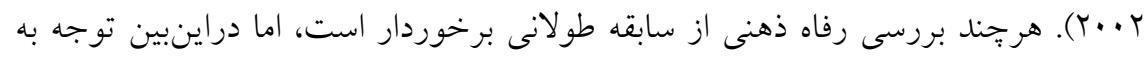
رفاه ذهنى كودكان نسبت به ساير حوزهها متأخرتر است. در ارزيابى رفاه ذهنى كودكان به ارزيابى رضايت، خشنودى و شادى آنها نسبت به ايدهآلهاى زندكى شان برداخته مىشود

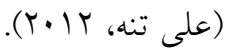

مسئله محدوديت ترجمههاى حوزه رفاه در علوم اجتماعى نيز به عدم شفافيت كامل تمايز معانى دامن مىزند. غالب ترجمهها از وازه Subjective well-being در حوزه روانشناسى و با معناى بهزيستى صورت كرفته است. به استناد نمونه يزوهشهاى خارجى حوزه علوم اجتماعى كه از وازه Subjective well-being بهمنظور ارزيابى رفاه ذهنى كودكان استفاده Sردهاند، در يزّوهش حاضر نيز وازه رفاه ذهنى معادل كلمه لاتين Subjective well-being است و در بخشهايى از يزوهش كه به مقالات ترجمهشده فارسى حوزه روانشناسى ارجاع مى دهيم جهت رعايت امانت از وازه بهزيستى يا بهزيستى ذهنى استفاده مىشود. بر اساس مطالعات اوليه جنين به نظر مىرسد كه بيشترين توجه حوزه رفاه در علوم اجتماعى مربوط به معلولان، سالمندان و زنان بوده است. در واقع مسائل رفاه كودكان 
بهندرت در منابع به جشم مىخورد و بهصورت جزيرهاى و اغلب در قالب ترميمى (مثلا

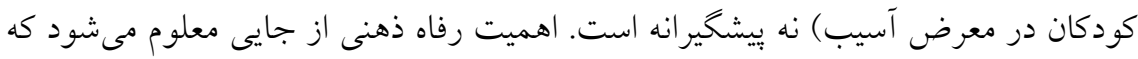

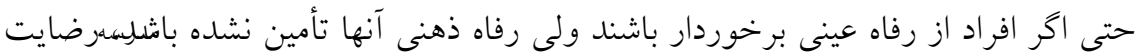
كافى از زندگى نخواهند داشت.

غفلت از مسئله كودكان نه در ايران بلكه در ساير كشورها نيز از سابقه برخوردار است كه كيسيس' و همكاران به عمدهترين دلايل اشاره كردهاند. از يكسو كمبود يزوهشهاى كودكان را مربوط به بيجِيدگى بررسى موضوعات اين گروه مىدانند كه در صورت وروده،

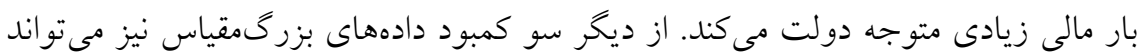

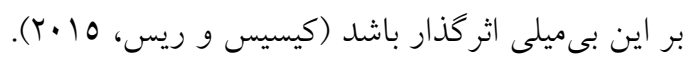

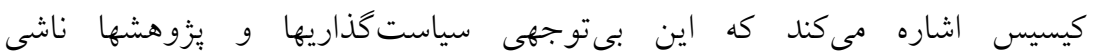
از كمبود اهميت سياسى كودكان نيز هست. در سالهاى اخير تلاشهاى مربوط به توسعه سنجهاى رفاه ذهنى كودكان اثربخش بوده و رفاه ذهنى برخى كودكان در كشورهاى مختلف ارزيابىشده است (كروسمنوس و همكاران، 10 (Y). اكنون اين نياز احساس مىشود كه بايد بر عوامل مؤثر تمركز بيشترى داشت. بن اريه'

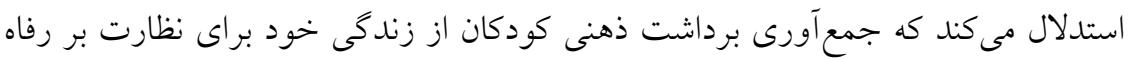

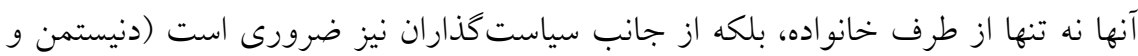

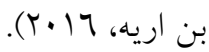

تاكنون در ايران بهطور منسجم و مشخص درباره موضوع رفاه كودكان يزوهشى صورت نخرفته است. نكته مسلم اينكه در حوزههاى اجتماعى كمتر به كودكان بهعنوان يكى كروه

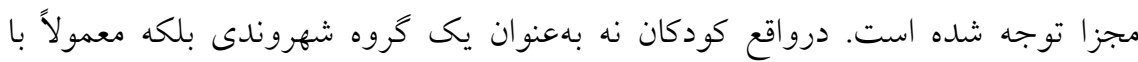


The Relationship between Communities and Subjective Well-Being of Children ...

كروه خانواده يكسان تلقى مىشوند. با مرورى بر مباحث نظرى و بزوهشهاى علمى به سهولت متوجه مىشويم كه سياستهايى كه مختص خود كودكان باشد و به تفويض حقوق و مزاياى كودكان جداى از خانو اده برداخته شود بسيار محدود است. اين كمبود مطالعات و يزوهشهاى حوزه كودكان، در موضوع رفاه ذهنى كودكان بهعنوان موضوعى نسبتاً جديد، بيشتر به جششم مى خورد.

توجه به رفاه ذهنى كودكان، تغييرات سياستى و وضع قوانين بهتر در راستاى بهبود

رفاه ذهنى كودكان شامل سياستهاى خانواده، مدرسه و نظام آموزشى يا حتى بهبود وضعيت فراغتى و امنيتى كودى را به دنبال خواهد داشت. در لايههاى پِيينتر خود خانواده نيز با آكاهى از مؤلفههاى رفاه ذهنى كودى، همخام با تأمين رفاه مادى، در جهت ارضاى نيازهاى ذهنى كودكان نيز برنامههايى ترتيب خواهند داد. درنتيجه مسئله عوامل مؤثر بر رفاه ذهنى كودكان براى سياستمداران، خانوادهها، مدارس، معلمان و ديخر افراد مرتبط حايز اهميت است. عوامل مؤثر بر رفاه ذهنى را در گروه اجتماعات و حوزهها مىتوان از يكديخر تميز داد'، براى جلو گيرى از ابهام و نيز متمايز كردن اين دو كروه از يكديخر، در اين مقاله تنها به اجتماعات مؤثر بر رفاه ذهنى كودكان برداخته و در بيزوهشهاى ديخرى موضوع مقولات مؤثر بر رفاه مورد مداقه قرار خواهد گرفت. -در بررسى عوامل مؤثر بر رفاه از 7حكصاحبه

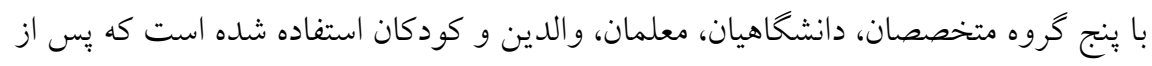
تحليل عاملى گويهها مشخص شد، دو گروه متمايز حوزههاى زندكى و اجتماعات بر رفاه ذهنى كودكان مؤثر هستند. منظور از حوزههاى زندكى موضوعاتى همجِون مشاركت، روابط

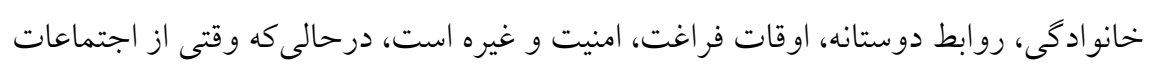
صحبت مى شود، اجتماعاتى تجون مدرسه، خانواده، محله و دوستان را شامل مىشود. در

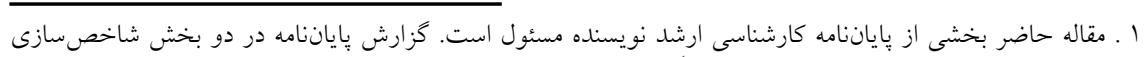

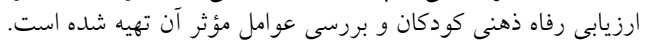


مقالهاى مجزا تأثير حوزههاى زندگى بر رفاه ذهنى كودكان گزارش خواهد شد.- از همين رو سؤالات اصلى يُزوهش حول محور اجتماعات است كه عبارتند از جهه اجتماعاتى بر رفاه ذهنى كودكان اثر مى گذارد؟ حضور كودكان در كدام جوامع تفاوتهاى اساسى و وبايدار در

$$
\text { رفاه ذهنى كودكان به وجود مى آورد؟؟ }
$$

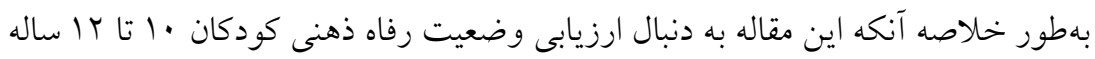

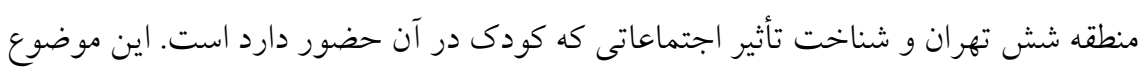

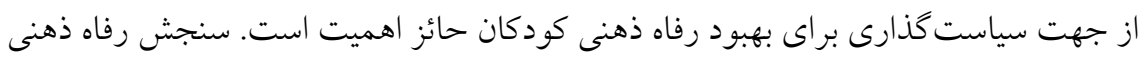

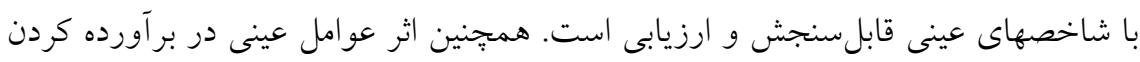

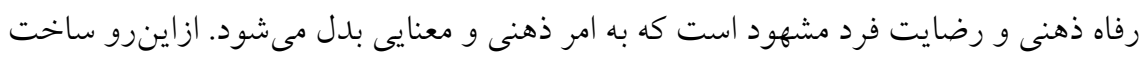

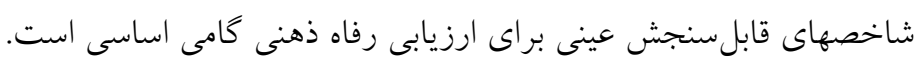

\section{مبانى نظرى}

كو اسومى به نقل از دينر و سو بيان مى كند كه رفاه ذهنى همر اه با شاخصهاى اقتصادى و

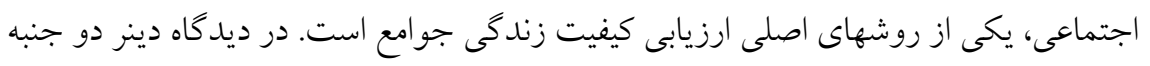

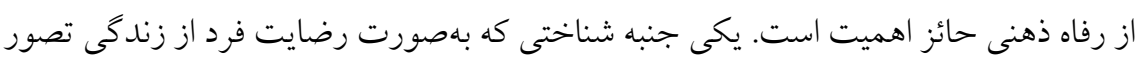
مىشود و ديخرى جنبه عاطفى كه معمولاً بهصورت احساس شادى يا ناراحتى افراد يا تعادل

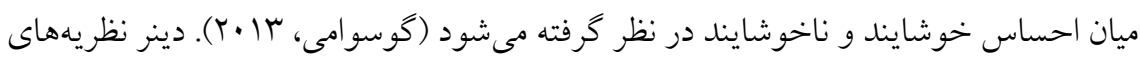

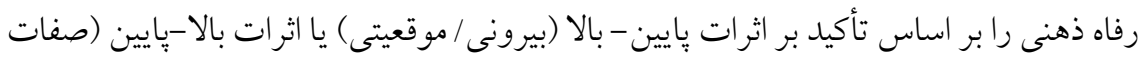

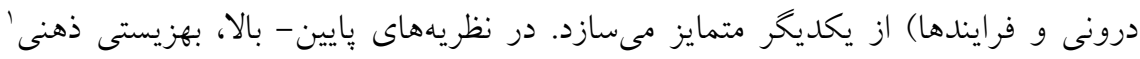

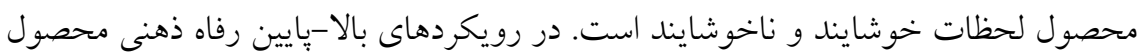

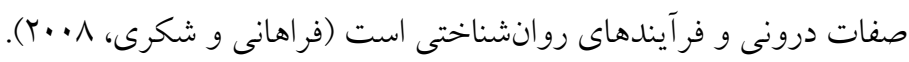


The Relationship between Communities and Subjective Well-Being of Children ...

برخى مطالعات تأثير صفات شخصيتى بر رفاه ذهنى كودكان (با زيرمقياسهاى برونخرايى، وظيفهشناسى، ثبات عاطفى و باز بودن) را نشان داده است. براى مثال ويترسو ( (. . ب) بين ثبات عاطفى و برونخ ايى با رفاه ذهنى در بين عجr نوجوان 19 ساله نروزى بررسى انجام داد و ثبات عاطفى ييشبينى كننده بسيار قوى رفاه ذهنى شناخته شد (به نقل از كوسوامى، r| (Y). اخر جهه مطالعاتى از اين قبيل بينش مفيدى در مورد ارتباط بين شخصيت نوجوانان و رفاه ذهنى آنها ارائه كرده است اما با كذر زمان يزوهشهايى كه براى تأييد تأثير صفات شخصيتى بر رفاه ذهنى در كروههاى كودكان و جوانان انجام مىشد، كمتر موردتوجه قرار كرفت.

دينر و همكاران (1990) ضمن تأييد تأثير صفات شخصيتى بر بيشبينى بهتر رفاه ذهنى افراد، بر تفاوت افراد كشورهاى مختلف و يا فرهنخهاى متفاوت نيز تأكيد مى كنند و جمعآورى دادههاى طولى از كودكان و نوجوانان را ضرورى مىدانند (دينر، 0. مب).

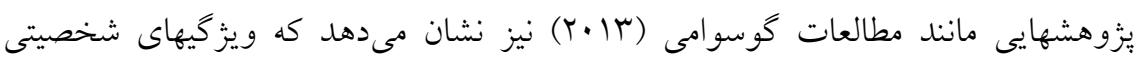
درصد ناجيزى (1) (1 درصد) از واريانس رفاه ذهنى كودكان را نشان مىدهد و بخش عمده (1) (1 درصد) غيرقابل توضيح است. در رابطه با كودكان به نظرمى آيد رويكرد يايين به بالا و بررسى نقش عوامل محيطى اهميت بيشترى يافته است (كيل مين و همكاران، عا •Y). درنتيجه ارتباط بين سياست گذارى اجتماعى و رفاه ذهنى مىتواند بهعنوان راه ميانجى باشد

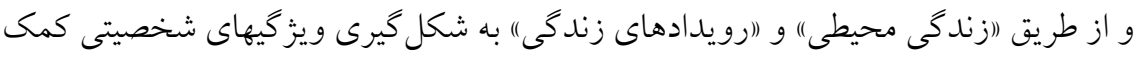

$$
\text { كند (كيل مين، عا • (Y) }
$$

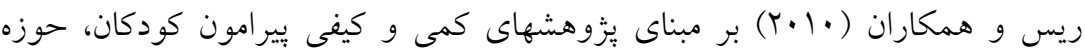
شاخصهاى رفاه ذهنى كودكان را توسعه دادند. تفاوت اين شاخص با سنجههاى ديخر رفاه ذهنى كودكان مانند مقياس رضايت از زندكى دانش آموزان كه بهطور كستردهاى استفاده شده 
است، به اين خاطر است كه اين تحقيق بهجاى شاخصهاى اقتباسشده از والدين مبتى بر

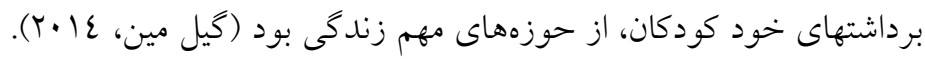

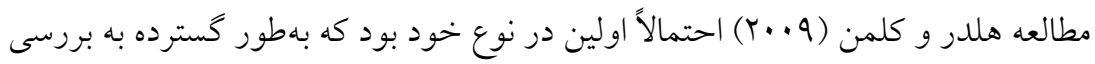
ارتباط شبكه كسترداى از روابط اجتماعى در هردو جنبه مثبت و منفى با شادى كودكان

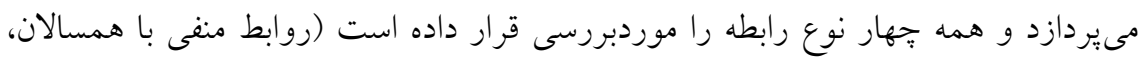

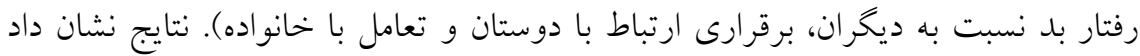
كه هر جهار نوع رابطه با شادى داراى ارتباط بوده و ييشبينى كننده شادى كودكان است.

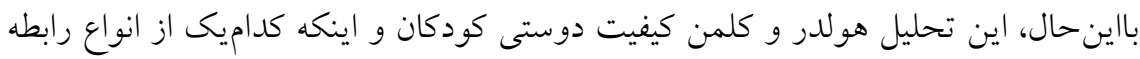

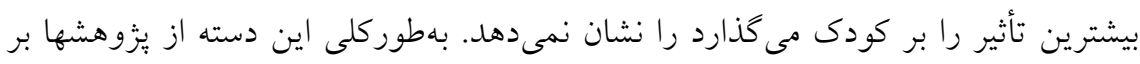

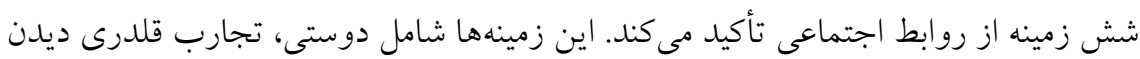

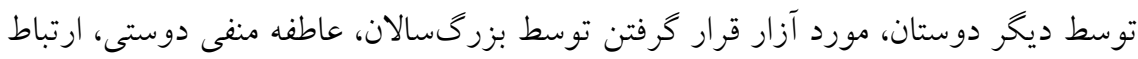

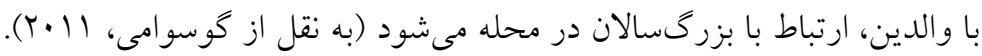

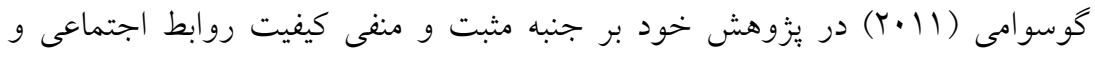

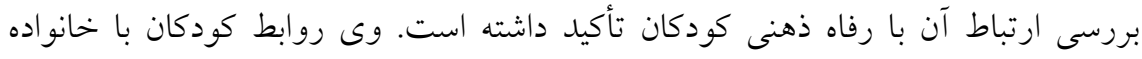
و بزرگسالان در محله و جنبههاى مثبت دوستى را موردبررسى قرار داد. از سوى ديخر،

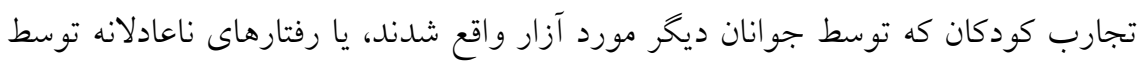

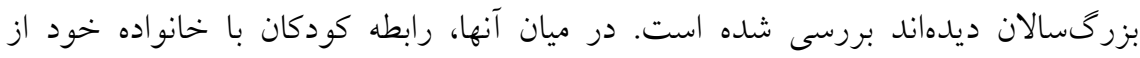

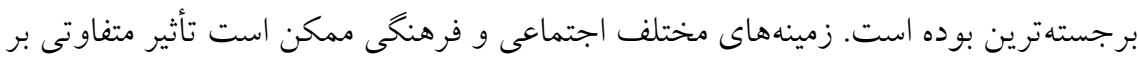

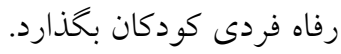

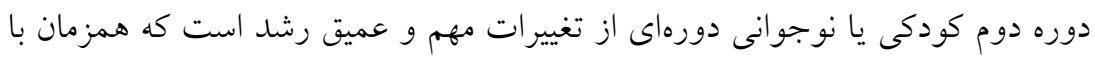

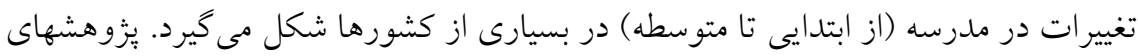


The Relationship between Communities and Subjective Well-Being of Children ...

محدودى بهطور خاص بر دوره كودكى و نوجوانى تمركز كرده است و اين تعداد محدود كودكان و نوجوانان را در مقايسه با بزرگسالان داراى رفاه ذهنى بالايى مىدانند (كيسيس و همكاران، با. Y) و يك كاهش تدريجى رفاه ذهنى از اول نوجوانى تا انتها ديده مىشود (كاراسكو و همكاران، Y. V). در اين سن از نظر رشد مغز، غدد، احساسات، شناخت، رفتار و روابط بين فردى تغييراتى اتفاق مى افتد (زاكسكين، ع (†). همجنين در ميان ديخران بودن، فشار مدرسه و نخرانى جهت تعلق و فشار همسالان، جنبهاى فيزيكى، شناختى، روانى و اجتماعى عميقاً دوران بلوغ را تغيير مىدهد. مطالعات مقطعى اجازه نمىدهد كه تغييرات فردى يا مربوط به مجموعه افراد را از هم تشخيص دهيم و شكاف موجود را برطرف كنيم (كاراسكو و همكاران، 17 (r. (r).

در سويى ديخر تفاوت رفاه ذهنى بين جنسها در كودكان و نوجوانان، در حوزههاى خاص زندكى گزارششده است. يزوهشهاى معدودى تأثير جنسيتى صرف را بر تفاوت سطح رفاه ذهنى بين كودكان و بزرگسالان نشان مىدهند (كيسيس و همكاران، V...

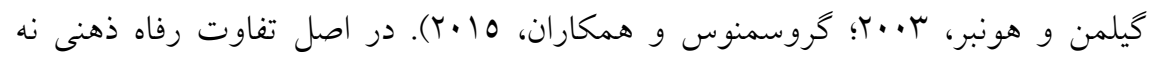
صرفا ناشى از جنسيت، بلكه در هر گروه جنسيتى در حوزههاى مختلف زندگى رفاه ذهنى

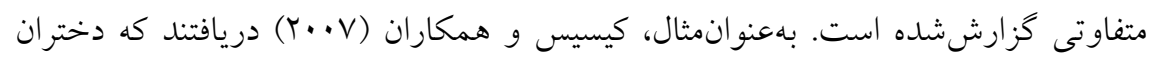
זا تا 17 ساله نمره رضايت بالاترى نسبت به يسران همان سن در حوزه يادگيرى گزارش مى دهند. درحالى كه يسر ان نمره رضايت بالاتر در فعاليتهاى فيزيكى نسبت به دختران دارند

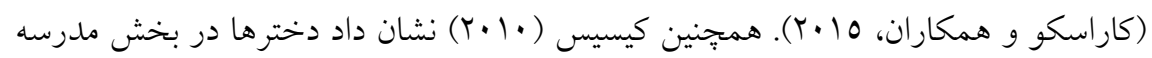
رفتن و روابط بين فردى از رفاه ذهنى بالاترى برخوردار هستند (برادشاو و همكاران II •؟؟

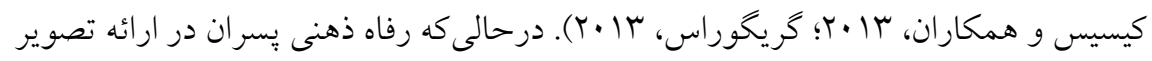

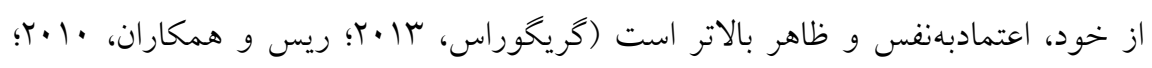
كيسيس، (1) همجنين روند كاهش رفاه ذهنى بِّران و دختران متفاوت است. اين كاهش 
احتمالاً در ميان دختران طولانىمدت تر است. به اين معنى كه سيستم خود بِايدارى دختران

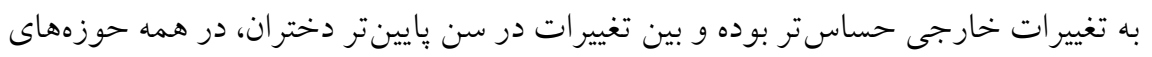

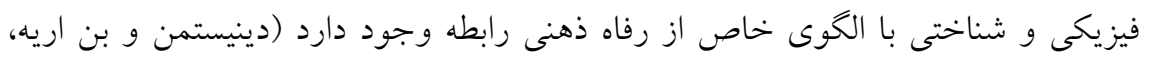

اولين درى كودكان از رفاه ذهنى (يسران و دختران) درخصوص درى آنان از ايمنى در

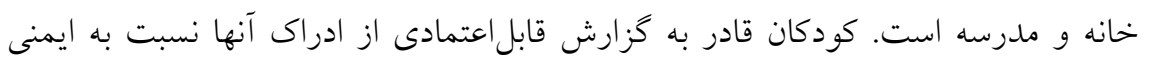
در شرايط مختلف هستند. در بررسيهاى بن اريه از مقايسه امنيت كودكان، ادراك كودكان

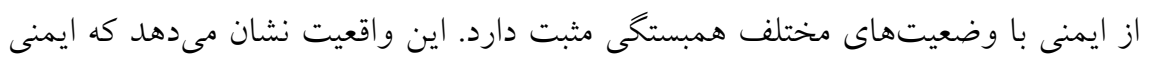

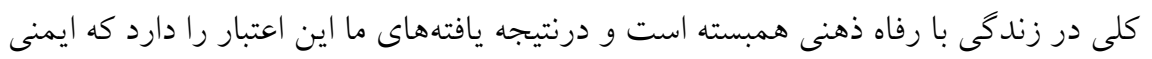
يك موضوع فراگير در زندكى كودكان است كه نهتنها در حوزه فردى بلكه به بطور كلى بايد

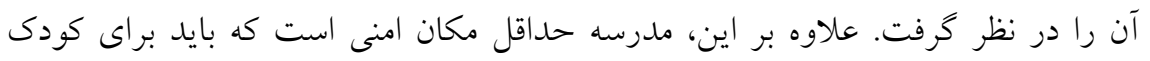

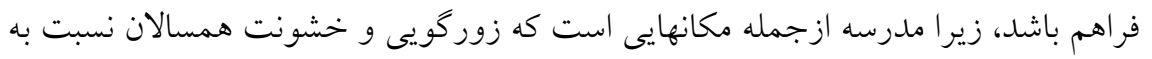

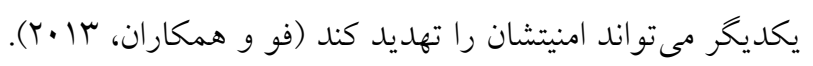

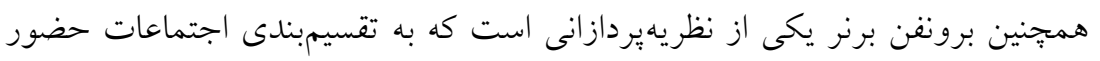

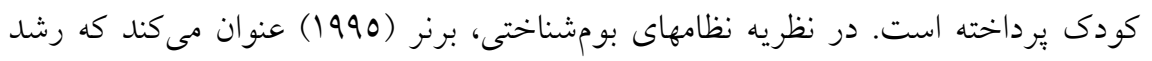

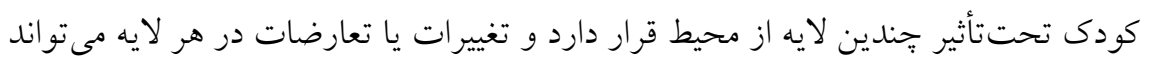

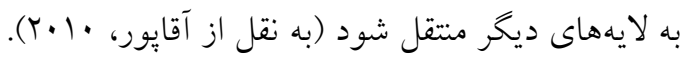

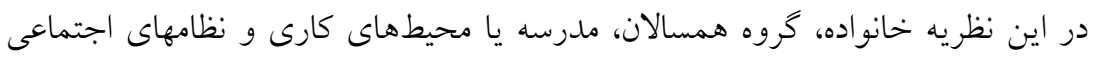

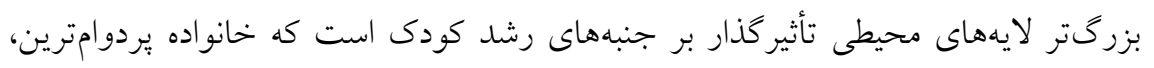

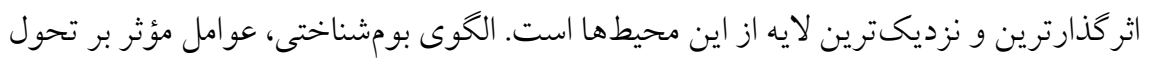

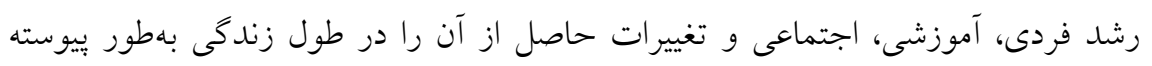

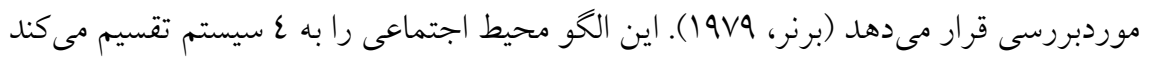


The Relationship between Communities and Subjective Well-Being of Children ...

كه عبارت از سيستم كو جك، سيستم ميانى، سيستم برونى و سيستم بزرگ است. سيستم كو جك: اين سيستم شامل خانو اده كه متشكل از كودك، والدين و خواهر و برادر است و همه اين اعضا بر يكديخر تأثير متقابل دارند. عملكرد خانواده با متغيرهاى مربوط به اعضاى آن ارتباط دارد. عوامل مربوط به والدين مانند سن، شخصيت، وضعيت مالى، شغلى، سطح تحصيلات و وضع سلامتى والدين بر عملكرد خانو اده تأثير گذار است. سيستم ميانى: سيستم كوجى خانواده تحتتأثير سيستم ميانى كه آن را احاطه كرده است، قرار مى گيرد. سيستم ميانى شامل محيطهايى ازجمله خانو اده گسترده شامل بدربزرگ و مادربزرگ، همسايخان، همكاران و دوستان مىشود كه خانو اده در آن شركت فعالانه دارد. سيستم برونى: سيستم ميانى خود تحت نفوذ سيستم برونى قرار دارد. اين سيستم شامل محيطهاى اجتماعى ازجمله رسانهاى كروهى، سيستم آموزشى، خدمات رفاهى، اجتماعى، درمانى و حمايتى مى شود.

سيستم بزرگ: سيستم بزرگ يا آخرين لايه به نخرشها، فرهنگ، باورها و ارزشهاى

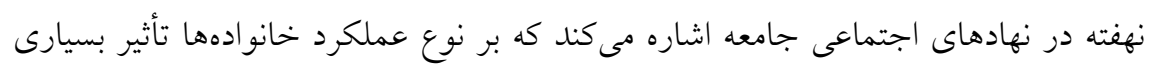
مى گذارد. اخر فرهنكى بر ارزشهاى انسان دوستانه تأكيد داشته باشد، نتيجه آن نخرشهاى مثبت

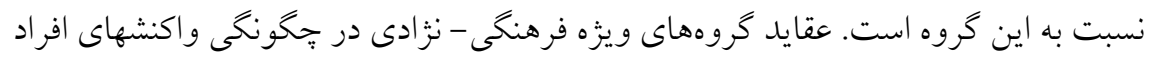
در برابر اين موضوع دخالت دارد (ساريخانى، عا +r). اواخر كودكى يا اوايل نوجوانى دورهاى است كه كودى با كشمكش و تعارضهايى مواجه مىشود. افراد بيشتر دركير فعاليتها مىشوند، خود هماهنكى بيشترى را تجربه مى كنند، انتظار بيشترى از زندگى دارند و درنهايت برخوردارى از رفاه در اين سن نيز مقوله مهمى تلقى مى شود (لواسانى، سان. (Y). يكى از تقسيمبنديهاى مرجع در ايران، تقسيمبندى كانون يرورش فكرى كودكان و 
نوجوانان درباره دوره كودكى و نوجوانى است. اين تقسيمبندى شامل گروه الف (آمادكى

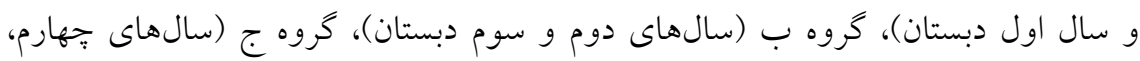

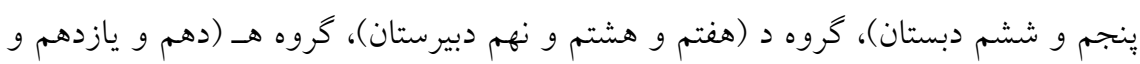

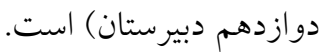

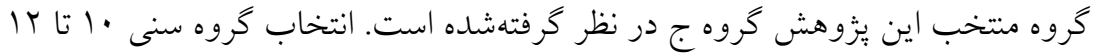
ساله، به بيروى از مطالعات يونيسف و مطالعات انجامشده بر رفاه ذهنى كودكان در نمونههاى خارجى است. كودكان اين دوره به سطحى از رشد عقلى رسيده و مىتواند درك درستى از مفاهيم انتزاعى داشته باشند. باوجوداينكه يُزوهش حاضر مبتى بر يافتهاى كيفى بر اين عوامل دست يافته است،

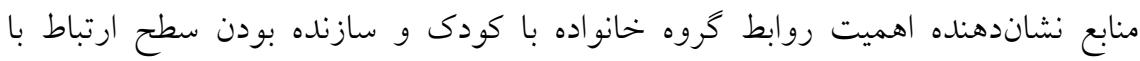
دوستان و همسالان و ساير بزرگسالان است و بحث امنيت روانى كودى در اجتماع خانه،

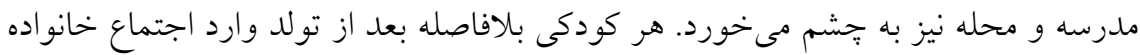
مىشود. اولين محيط رشد، يرورش، فعاليت و ارتباطات كودى خانواده است. بعد از خانو اده

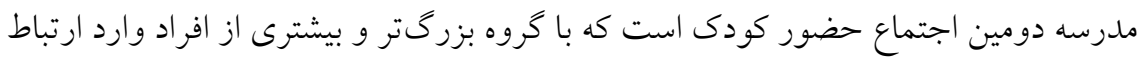

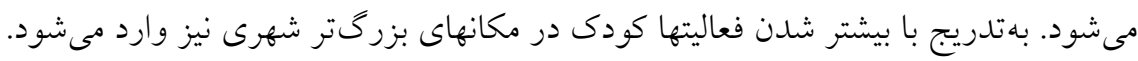

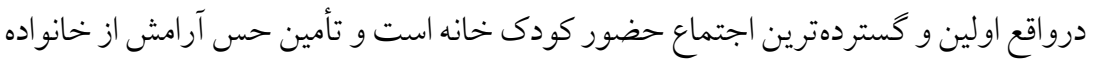
به ساير اجتماعات هم متتقل مىشود. در درجه دوم مدرسه و بهويزه افراد حاضر در مدرسه امنيت

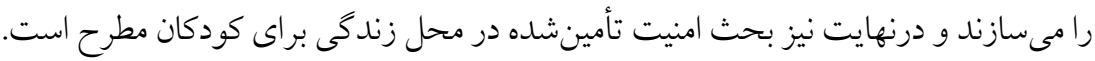

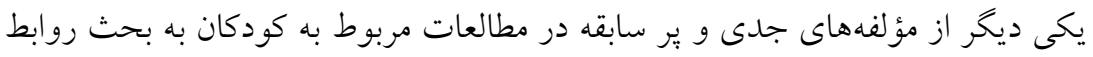

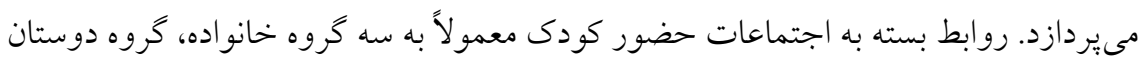
و همسالان و معلمان مدرسه قابلتقسيم است. رفاه ذهنى كودكان، قضاوت نسبت به زندگى و مجموعه احساسات مثبت و منفى كودى 
The Relationship between Communities and Subjective Well-Being of Children ...

نسبت به موقعيت و شرايط است. بنا بر ديدگاه ريس'، رفاه ذهنى از دو جنبه عاطفى و شناختى ساخته مىشود كه يزوهش حاضر بر هر دو جنبه توجه كامل داشته است و عاطفه مثبت/ منفى كودى، رضايت كلى از زندكى و رضايت از حوزههاى مختلف زندكى كودكان را موردمطالعه قرار داده است. در راستاى بررسى تأثير اجتماعات كودى بر رفاه ذهنى، تأكيد بيشتر بر رضايت كودى از زندگى و بررسى وضعيت اجتماعات از نظر كودى (خوداظهارى)

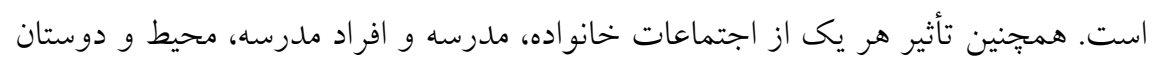
(سيستم كوجى، ميانى و برونى) بر احساس رضايت كودكان از زندگى بررسى مىشود. شواهد حاكى از آن است كه بيشترين توجه به رفاه در ايران مربوط به معلولان، سالمندان و زنان بوده است و بيشترين توجه به كودكان شامل گروه در معرض آسيب است. شيانى (r. . (Y) در مطالعهاى با عنوان (مشاركت اجتماعى كودكان) به يكى از ابعاد نوين مشاركت اجتماعى، يعنى مشاركت كودكان اشاره مى كند. فرض بر نياز جامعه ايران به تحول انديشه و تكامل راههاى مشاركتى است تا از اين طريق هر كودكى راههاى ايفاى نقش را كشف كند و به ارائه راهكارهايى جهت بهبود وضعيت مشاركت كودكان بيردازد. در باب رفاه ذهنى و عوامل مؤثر بر آن، نيلى و همكاران (T) (T) در يزوهشى با عنوان (شناسايى عوامل مؤثر بر رفاه ذهنى در ايران) نشان دادند كه عوامل درآمد، وضعيت شغلى، سلامت فردى، اعتقادات مذهبى، روابط و ييوندهاى خانوادگى، سن و جنسيت بر سطح رفاه شهروندان اير انى تأثير خذار هستند.

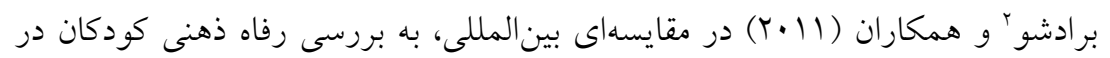
دو سطح تحليل ماكرو، بين المللى (اتحاديه ارويا) و سطح ميكرو، ملى (انخليس) برداخته و دريافتند كه در سطح خرد رفاه شخصى با داشتها و شرايط خانه داراى ارتباط است ولى

2. Bradshaw 
با ساختار خانواده و روابط خانوادكى ارتباط نشان نمىدهد. رفاه در مدرسه با هيج متغيرى

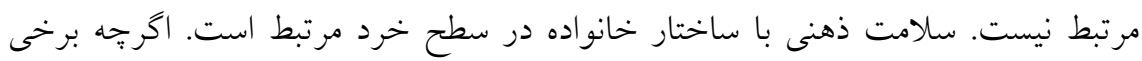

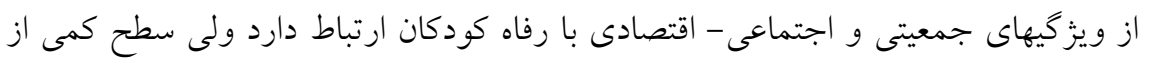
تغييرات را به خود اختصاص دادهاند.

در باب روابط اجتماعى و رفاه ذهنى كودكان، كوسوامى' (Y. T) در يك يزوهش ملى بين

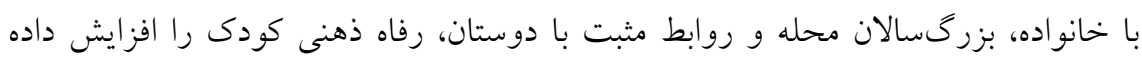

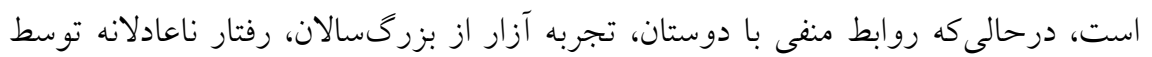

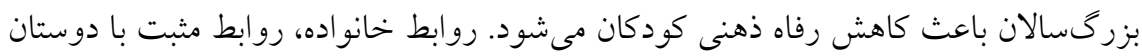

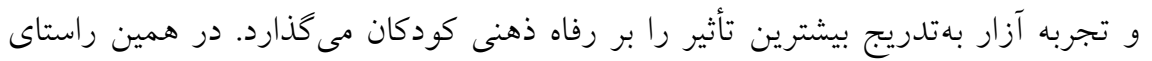

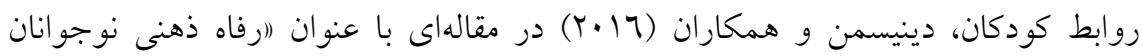

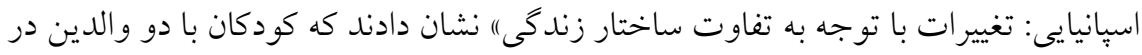
همه حوزهها از رفاه ذهنى بهترى برخوردار هستند. همجنين به ترتيب كودكان تحت حمايت، كودكان تك والدين و درنهايت كودكان دو والدين از ثبات زندكى متفاوتى برخوردارند كه كودكان تحت حمايت كمترين ثبات، بعداز آن كودكان تك والدين هستند. رفاه امرى بسيار بيّيجيده است، به همين خاطر ينداشته مردم نسبت به مقوله رفاه و

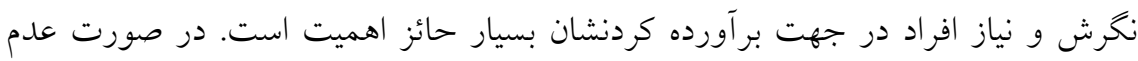
توجه به اين مسئله، ممكن است دولتها ضمن تلاشهايى با هزينه هنكفت مالى و زمانى، كز

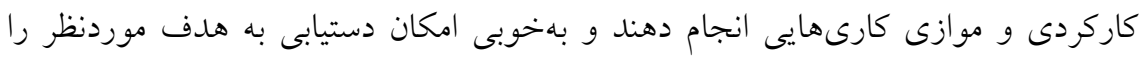

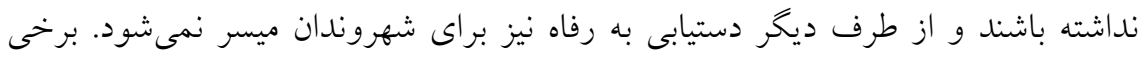
نويسندكان و متخصصان رفاه ذهنى كودكان، مانند بن اريه (ب0.0)، استدلال مى كنند كه 
The Relationship between Communities and Subjective Well-Being of Children ...

جمع آورى برداشت ذهنى كودكان و نوجوانان از زندگى روزانه خود براى نظارت بر رفاه آنها ضرورى است. جيزى كه بهنوبه خود اخر سياستمداران، بزشكان و جامعه بهطوركلى قصد تصميم گيرى آكاهانه در مورد مسائل مربوط به نسل جوان داشته باشند امرى مهم و قابلتوجه به نظر مىرسد (كاراسكو و همكاران، 17 (Y). توجه بيشتر به رفاه ذهنى كودكان مىتواند به تغيير و بيشرفتهاى خوبى در سياست گذاريها منجر شود. بررسى نيازها و علايق كودكان ازنظر خودشان و شفافتر شدن مسائلى مانند اهميت علاقهورزى والدين نسبت به كودكان، حق نظر و مشاركت عملى قائل شدن براى كودكان، ديد سياستمداران را گستردهتر كرده و به تغييرات بخشى از قوانين يا وضع قوانين جديدى در راستاى بهبود رفاه ذهنى كودكان منجر مىشود. اين تغييرات مىتواند شامل سياستهاى خانواده، مدرسه و نظام آموزشى يا حتى بهبود وضعيت فراغتى و امنيتى كودى باشد. در لايههاى يايين تر خود خانو ادهها نيز با آكاهى از مؤلفه رفاه ذهنى كودى، همخام با رفاه مادى، در جهت ارضاى نيازهاى ذهنى كودكان برنامههايى ترتيب دهند. براى مدرسه، معلمان و ديخر افرادى كه مرتبط با كودى هستند نيز اين مسئله كه رفاه ذهنى كودى عمدتاً از كدام متغير تأثير مىيذيرد حايز اهميت است. تعيين اينكه زنها و صفات شخصيتى، شرايط زيستمحيطى و ويزّيهاى جمعيتى تا جهه ميزان و در جهه حوزههايى تفاوتهاى اساسى و پايدار ذهنى در كودكان به وجود مى آورد يا اينكه جهه ميزانى از احساس رضايت، موفقيت و سلامت روان كودك با رفع نياز و خواسته هايش مرتبط است. اين قبيل بزوهشها به همه كروههاى والدين، مدارس و نظام آموزشى و حتى مهلكودكها، در راستاى ارتقاى كيفيت آموزش كودكان بهعنوان حساسترين كروه آموزشى خدمت ارزندهاى ارائه مىدهد. در سطح كلان نيز بيشنهادها در تعيين و تغيير سياست كذاريهاى حوزههاى مختلف ويزه كودكان اثر كذار خواهد بود.

مرور مطالعات داخلى نشاندهنده اين موضوع است كه در بين مطالعات انجامشده 
فارسى به مسئله كودكان توجه نشده است و هيج يزوهشى در حوزه رفاه ذهنى كودكان

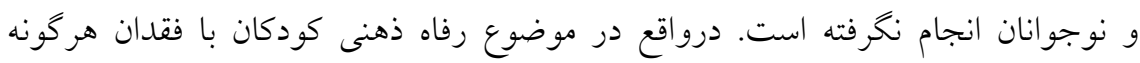

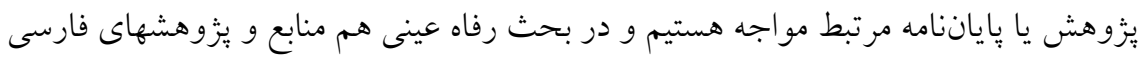

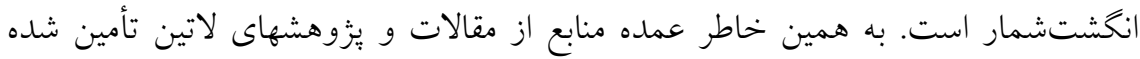

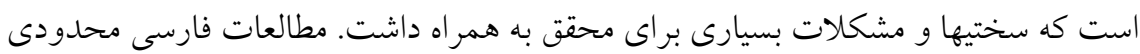

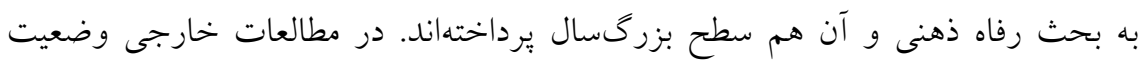
متفاوت است، يزوهشهاى بسيارى بر رفاه ذهنى كودكان، جنبها و ابعادشان متمركز هستند.

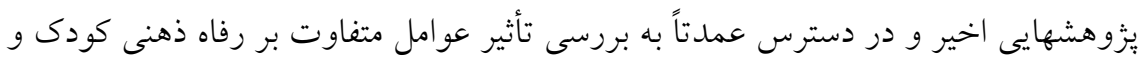
يا مقايسهاى تطبيقى بين وضعيت رفاه ذهنى كودكان در بين كشورهاى مختلف يرداختهاند. قديمى بودن و در دسترس نبودن منابع و مقالاتى كه بهصورت كامل سنجههاى ارزيابى رفاه ذهنى كودى و نحوه ساخت اين سنجهها را توضيح دهل، به تأكيد بيشتر بر مصاحبهها و خروجى بومى كار براى ساخت سنجهها منجر شد. بر اساس مباحث مطرحشده در اين بخش، مدل نظرى يزوهش در شكل شماره ( (1) قابل مشاهده است.

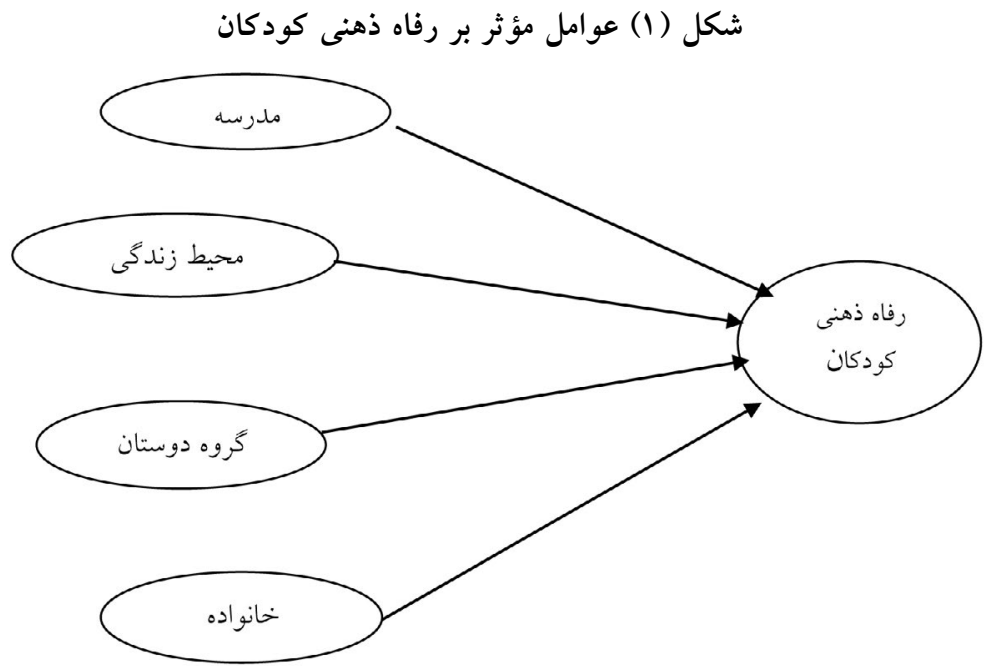


The Relationship between Communities and Subjective Well-Being of Children ...

\section{روش}

\section{ماهيت و روش تحقيق}

يزوهش ييشرو از حيث هلف در زمره تحقيقات كاربردى و بر اساس ماهيت دادهها از نوع كمى شناخته مىشود كه از منظر روش جز تحقيقات بيمايشى است. هدف ارزيابى اجتماعات مؤثر بر رفاه ذهنى كودكان r ا-- ا ساله منطقه شش تهران است كه انتخاب منطقه شش بهعنوان ميدان يزّوهش دلايل متعددى دارد كه مهمترين آن دسترسيذيرى و شناخت منطقه جهت محقق است.

\section{جامعه آمارى، حجم نمونه و روش نمونه}

جهت سنجش اجتماعات مؤثر بر رفاه ذهنى كودكان از روش بيمايش و برسشنامه استفاده

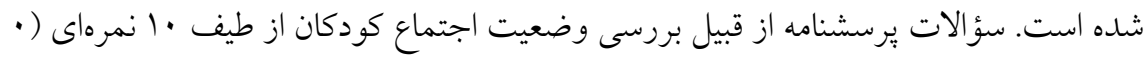
اصلاً- · ا خيلى زياد) استفاده شده است. با توجه به كودى بودن جامعه آمارى تحقيق، رعايت ملاحظات اخلاقى با دشواريهايى همراه بود. باين حال براى رعايت اصول اخلاق يزوهش طبق جارجوب بازمان آموزشويرورش، با هماهنكى آموزشويرورش منطقه شش، تأييد مديران مدرسه و در حضور معلمان فرايند توضيح نحوه يزوهش و آثار آن براى كودكان شفاف شد. جامعه آمارى اين بيزوهش، دانش آموزان مقاطع جهارم تا ششم مدارس منطقه شش تهران

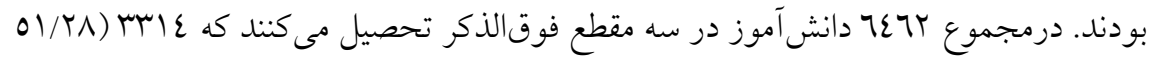

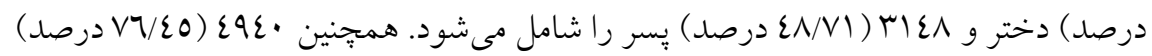
دانشآموز در حال تحصيل در مدارس دولتى و

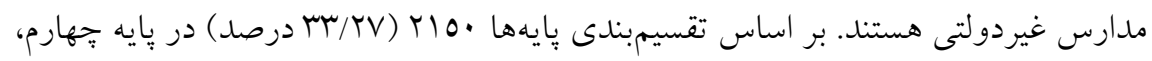
•

$$
\text { تحصيل هستند (سازمان آموزشويرورش شهر تهران، } 10 \text { •. (Y). }
$$


در اجراى بيمايش از روش نمونه گيرى خوشهاى جندمرحلهاى و مطبق استفاده شده

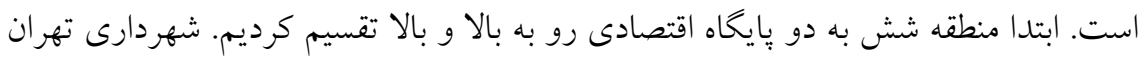

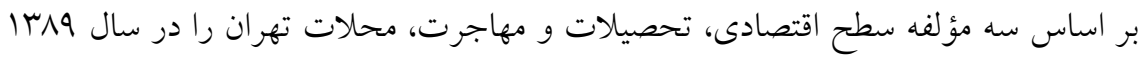
در ده خوشه طبقهبندى كرده است. مشاهده وضعيت منطقه 7 نشان مىدهد تمام محلات اين منطقه جزء ع خوشه بالا با ويزگى هاى اقتصاد متوسط رو به بالا و بالا، بىسو ادى كم و

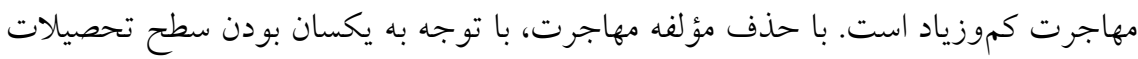

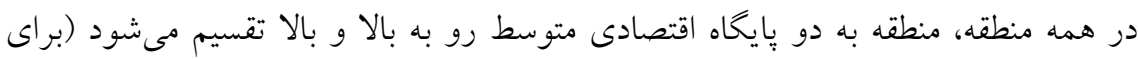

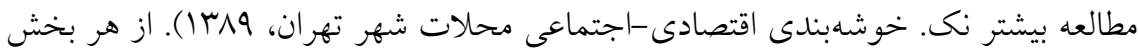
بهطور تصادفى دو مدرسه دولتى دخترانه و يُرانه و يك مدرسه غيرانتفاعى انتخاب شد.

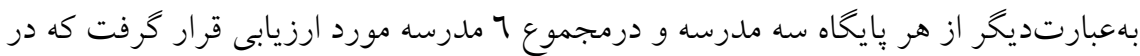

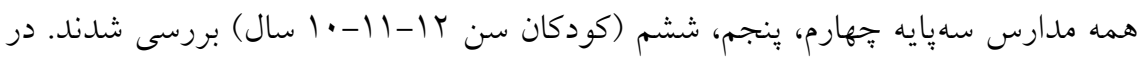

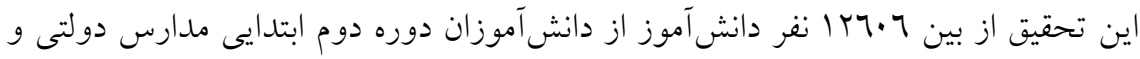

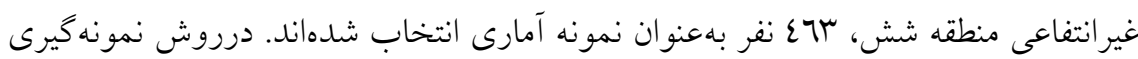
احتمالى هر يك از افراد شانس برابرى براى انتخاب شدن دارند. يافتهاى اين ئزوهش در دو بخش توصيفى و تبيينى ارائه شده است. براى تحليل

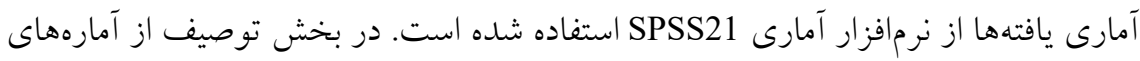

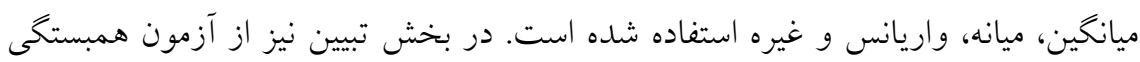

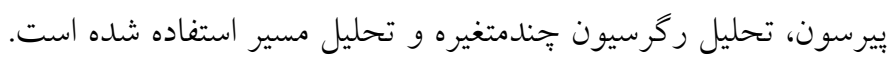

\section{سنجه ها}

رفاه ذهنى كودكان متغير وابسته و 0 اجتماع حضور كودكان مدرسه، افراد مدرسه (تحليل عاملى گوىهاى مربوط به مدرسه نشاندهنده وجود دو عامل مستقل مدرسه و افراد مدرسه 
The Relationship between Communities and Subjective Well-Being of Children ...

است)، محيط، خانو اده و دوستان متغيرهاى مستقل اين يزوهش را مىسازند. متغير وابسته در اين يزّوهش رفاه ذهنى كودكان (با دامنه · تا .(1) است. براى سنجش وضعيت رفاه ذهنى كودكان از يرسشنامه محقق ساخته استفاده شده است. (همانطور كه قبلتر بيان شد، محور اصلى پاياننامه ساخت شاخصهاى سنجش رفاه ذهنى كودكان بوده است. براى اين منظور با اجراى بزّوهش كيفى مؤلفههاى رفاه ذهنى كودكان شناسايى شد. يسازآن با طراحى برسشنامه و اجراى بيمايش

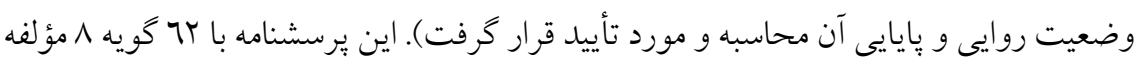
سازنده رفاه ذهنى را نشان مىدهد. نكته مهم اين يرسشنامه ارزيابى جزءبهجزء مؤلفههاى سازنده رفاه ذهنى است. اغلب شاخصهاى مربوط به رفاه ذهنى كودكان، آن را بهصورت كلى و نهايتاً با

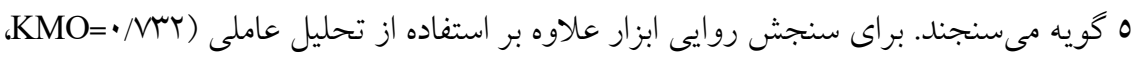

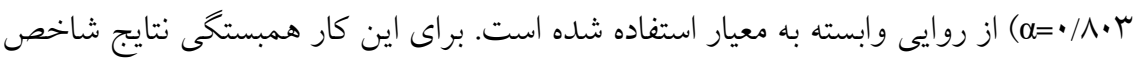
رفاه ذهنى با سنجههاى معتبر ( SLSS مقياس رضايت از زندگى دانش آموزان) و ( BMSLSS مقياس جندبعدى خلاصه رضايت از زندگى دانش آموزان) مورد ارزيابى قرار گرفت. نتايج آزمون همبستخى بيرسون به شرح جدول شماره ( ) خزارش مىشود.

جدول (1) آزمون همبستخى بيرسون بين سنجههاى معرف رفاه ذهنى كودكان (جدول 1)

\begin{tabular}{|c|c|c|c|}
\hline & BMSLSS & SLSS & متغير مستقل \\
\hline$r$ & rr. & 0.7 & \multirow{3}{*}{ شاخص رفاه ذهنى كودكان } \\
\hline$p$ &.$/ 99$ & .199 & \\
\hline$n$ & عor & zor & \\
\hline
\end{tabular}

قبل از يرداختن به وضعيت روايى و يايايى متغيرهاى مستقل، لازم است تعاريف نظرى و عملياتى اين متغيرها ارائه شود. در زير بهاختصار تعاريف متغيرهاى مستقل ارائه شده است. 
مدارس بلهعنوان يكى فرآيند رسمى آموزش با برنامه درسى معين تعريف مىشوند كه از

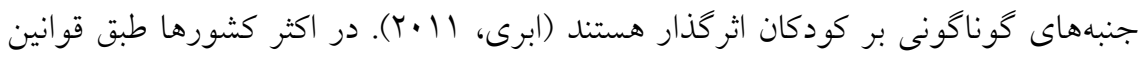

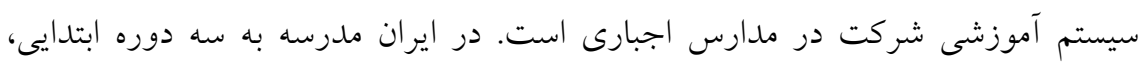
متوسطه اول و متوسطه دوم تقسيم مى شودد.

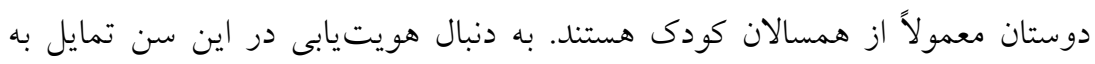

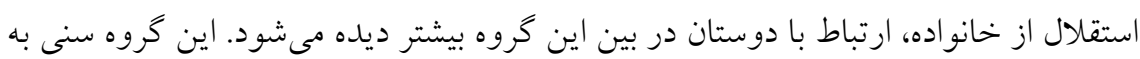

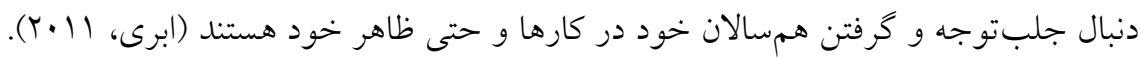

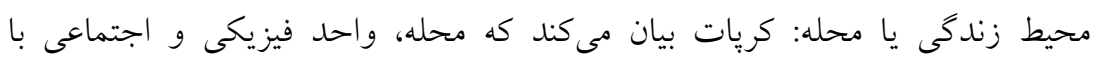

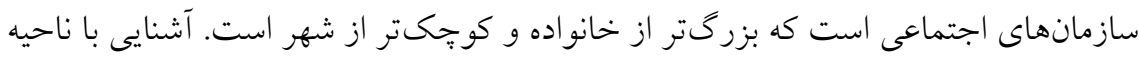

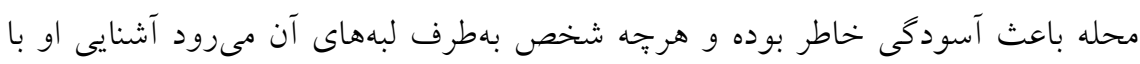

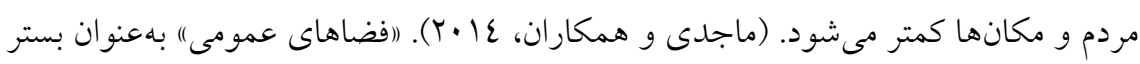
كالبدى حضور شهروندان و برقرارى تعاملات اجتماعى ايشان در محالت، نقش عمده و ودمان مهمى را از دونقطه نظر كالبدى سادراكى و اجتماعى ايفا مى كنند.

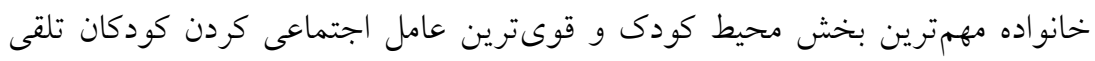
مىشود و رفتار اجتماعى را هدايت و ارزش و هنجار و اعتقادات را به كودى متنقل مى كند

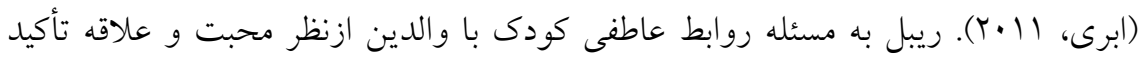

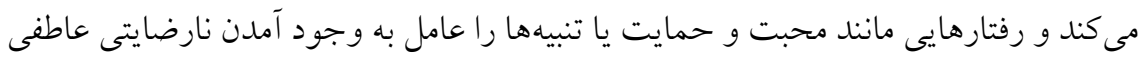
در كودكان مى داند. 
جدول (Y) تعريف عملياتى متغيرهاى مستقل بزٔوهش

\begin{tabular}{|c|c|}
\hline محله & خانو اده \\
\hline در محله ما فضاى كافى براى بازى و تفريح & 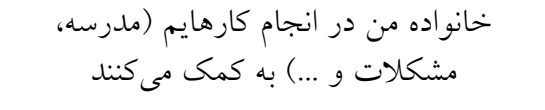 \\
\hline محل زندكىام را دوست دارم & بِدر و مادرم نسبت به همديخر مهربان هستند \\
\hline جيزهايى كه لازم دارم در محله وجود ندارد. & من در خانه احساس آرامش مى كنم \\
\hline محلهام را دوست دارم & دوست دارم بيشتر تنها باشمَّيا با افرادى غير از \\
\hline محله من فضاى امن براى بازى دارد & من خانواده خوشبختى دارم \\
\hline 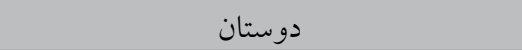 & افر اد مدرسه \\
\hline با دوستانم رابطه خوبى دارم & 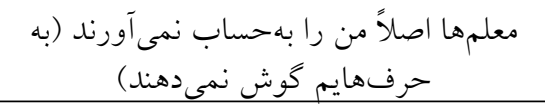 \\
\hline به تعداد كافى دوست دارم. & در ماه كذشته بعضى از همكلاسى هاى قلدرم \\
\hline دوستانم به من احترام مى گذراند. & در ماه كذشته برخى همكلاسى ها من را كروه \\
\hline در هفته گذشته زمان زيادى را با دوستانم & مل مدرسه \\
\hline در هفته كذشته زمان زيادى با دوستانم براى ماى ماند اندان & مدرسه رفتن را دوست دارم \\
\hline در مواقع نياز دوستانم به من كمك مى كنند. & از فعاليتهاى مدرسه لذت مىبرم \\
\hline & جيز هاى زيادى در مدرسه يـ \\
\hline
\end{tabular}




\section{اعتبار و وِايايى ابزار اندازهيرى}

جدول شماره (r) وضعيت روايى و بايايى متغيرهاى مستقل بزوهش ران را نشان ميدهد.

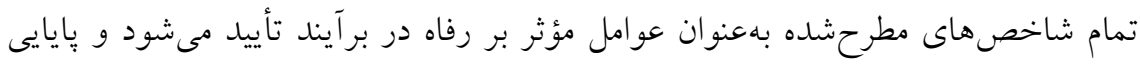
اين سازهها نيز تأييد مىشود.

جدول (r) گزارش وضعيت روايى و بايايى عوامل مؤثر بر رفاه ذهنى كودكان

\begin{tabular}{|c|c|c|c|c|c|c|}
\hline وضعيت & $\alpha$ & وضعيت & نمره متخصصين & KMO & اجتماع & رديف \\
\hline تأييد & $\cdot / V \wedge V$ & تأييد & . $/ M M A$ &.$/ 771$ & مدرسه & 1 \\
\hline تأييد & - /vav & تأييد & $\Lambda r$. & $7 . r$ & مدرسه (افراد) & r \\
\hline تأييد & $\cdot / \mathrm{V} \cdot \cdot$ & تأييد & $\cdot / 2 \wedge 9$ & . NIV & محيط & r \\
\hline عالى & - /Arq & عالى & $\cdot / \vee \wedge \varepsilon$ & . ATr & همسالان & $\varepsilon$ \\
\hline تأييد & $\cdot / v \cdot 1$ & تأييد & ./AV & $\cdot / N r q$ & خانو اده & ir \\
\hline
\end{tabular}

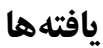

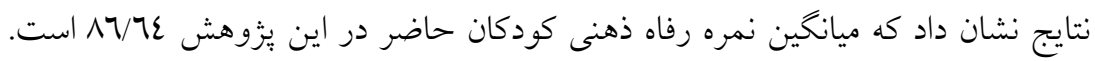

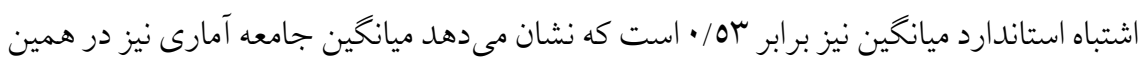

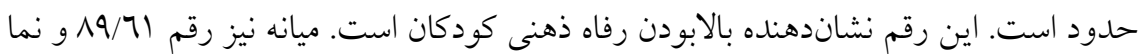

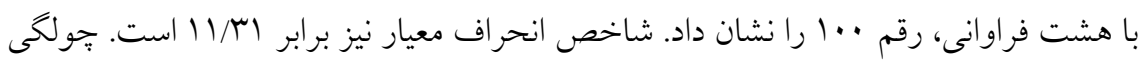

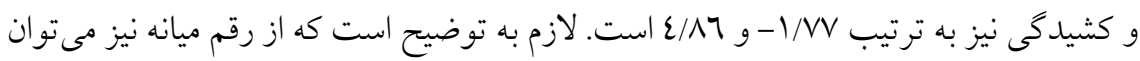
فهميد شاخص ييشرو همجيجون تمام شاخص هاى موجود درباره رفاه ذهنى كودكان تنها مى توان

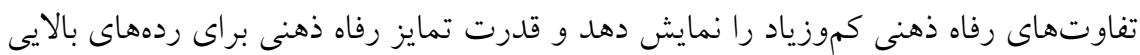

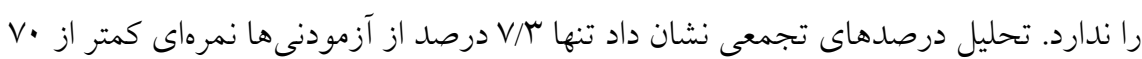

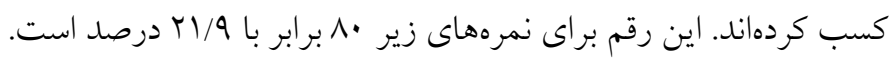




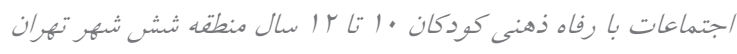

The Relationship between Communities and Subjective Well-Being of Children ...

جدول (ع) توصيف فراوانى نمونه آمارى بيروهش

\begin{tabular}{|c|c|c|c|}
\hline فراوانى (\%) & طبقات & فر اوانى (\%) & طبقات \\
\hline rרז (\%/vq/q & دولتى & $(\% \Sigma V / T) Y \backslash \varepsilon$ & دختر \\
\hline$(\% / r / 1) 91$ & غيردولتى & 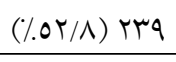 & ل بـر \\
\hline$(/ . \wedge \varepsilon / 1)$ YNI & متولد تهران & س & ساله •1 \\
\hline$(\% / 0 / 0) \mathrm{V}$. & متولد ساير شهرها & $(\% / r / q) \backslash \varepsilon q$ & ساله 11 \\
\hline (\%) & كل & $(\% / r 0 / 0) 171$ & ساله Y| \\
\hline
\end{tabular}

بر اساس نتايج بهدستآمده رفاه ذهنى پِّران با ميانخين ع/7/ و دختران با ميانخين NT/V0 تفاوت معنادارى وجود ندارد. اين عدم تفاوت توسط آزمون t با دو نمونه مستقل نيز

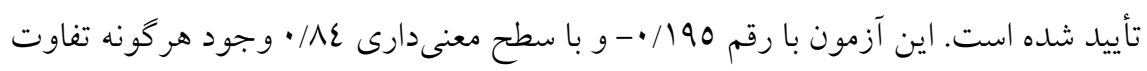
در ميانخين رفاه ذهنى را رد مى كند.

همجنين ميانخين رفاه ذهنى دختران و يُران در سنهاى ده، يازده و دوازدهسالكى نشان دادهشده است. مشاهده نمرات يك كاهش كوجّى از دهسالكى (

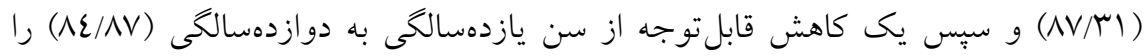
نشان مىدهد. همجنين ميانخين رفاه ذهنى دختران و پِّران در اين سالها بهصورت تقريبى (بهغيراز دهسالكى با • • • • تفاوت) برابر است.

\section{توصيف اجتماعات مؤثر بر رفاه ذهنى كودكان}

هر كودكى بلافاصله بعد از تولد وارد اجتماع خانواده مىشود و بعد از خانواده مدرسه، دومين اجتماع حضور كودى است كه با محيط بزرگتر و افراد بيشترى وارد ارتباط مىشود. بهتدريج با بيشتر شدن فعاليتها و گستره زندگى، كودى به مكانهاى بزرگتر شهرى نيز وارد مى شود و همه اين افراد و مكانها بر حس رضايت كودى از زندكى نقش خواهند داشت. 


$$
\text { شكل (Y) وضعيت اجتماعات تأثير گذار بر رفاه ذهنى كودكان }
$$

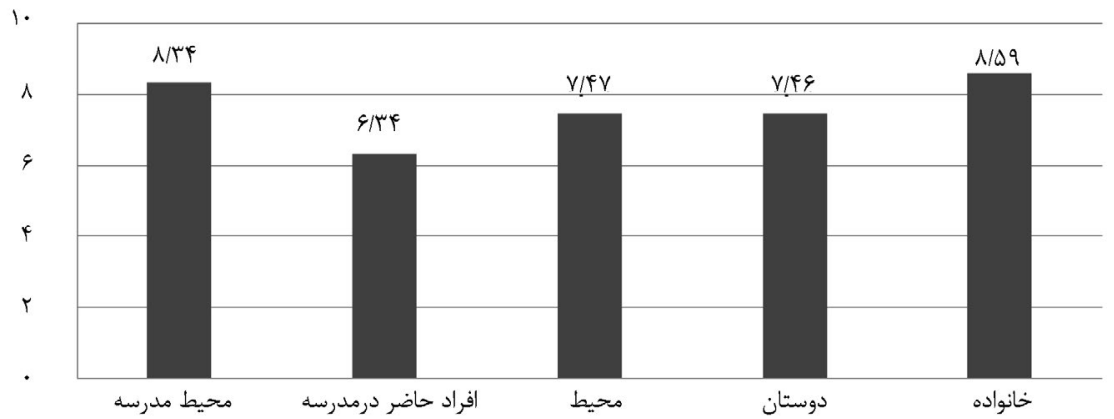

در توصيف اجتماعات مؤثر بر رفاه ذهنى ميانخين براى مدارس يسران ^^/N و براى مدارس دختران • •/ است. همجنين مدارس دولتى ميانخين آ// و مدارس غيردولتى عدد N/\{7 را نشان مىدهند. بررسى مدارس دولتى و غيردولتى بهصورت مجزا نشان مىدهد

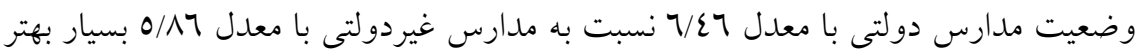

\section{تبيين اجتماعات مؤثر بر رفاه ذهنى كودكان}

بر اساس فرضيات مطرح شده يُزوهش در بخشهاى قبلى، تأثير على ينج اجتماع خانواده، دوستان، مدرسه، افراد مدرسه و محيط زندگى بر رفاه ذهنى كودكان موردتوجه اين مقاله است. بر اين اساس قبل از طرح فرضيات على ضرورى است كه رابطه همبستخى هر يكى از اين اجتماعات ينجگانه با رفاه ذهنى كودكان مورد ارزيابى قرار كيرد. جدول شماره (0) نتايج اين آزمون را نشان مىدهد. 
The Relationship between Communities and Subjective Well-Being of Children ...

جدول (0) آزمون همبستخى بيرسون بين متغيرهاى مستقل و رفاه ذهنى كودكان

\begin{tabular}{|c|c|c|c|}
\hline$P$ & $\mathbf{r}$ & $\mathbf{N}$ & متغيرهاى مستقل \\
\hline$<\cdot / \cdots \cdot \mid$ & $\cdot / \varepsilon q \varepsilon$ & Eor & خانو اده \\
\hline$<\cdot / \cdots \cdot \mid$ & .1091 & Eor & دوستان \\
\hline$\cdot / \cdot r V$ & . 1041 & عor & محيط زندگى \\
\hline$<\cdot / \cdots \cdot$ & $\cdot / \varepsilon V Y$ & Eor & فضاى مدرسه \\
\hline$\cdot / \cdot V$ &.$/ T \Lambda$ & Eor & افراد مدرسه \\
\hline
\end{tabular}

خانواده

فرضيه مطرح در اين اجتماع عبارت است از اينكه (ابه نظر مىرسد بين مطلوبيت اجتماع خانو اده و رفاه ذهنى كودكان رابطه مستقيم وجود دارد)،، يعنى هرجهه اجتماع خانو اده مطلوبتر باشد، رفاه ذهنى كودكان بيشتر و برعكس خواهد بود. در راستاى آزمون فرضيه بالا نتايج همبستكى رفاه ذهنى كودكان و وضعيت اجتماع خانواده با 99 درصد اطمينان تأييد شده است. رفاه ذهنى كودكان با شدت 9 ـ/ • و بهصورت مستقيم با اجتماع خانواده داراى همبستكى است. نتايج تحليل رگرسيونى دومتغيره نيز نشان داد كه بين وضعيت مطلوبيت اجتماع خانو اده و رفاه ذهنى رابطه على وجود دارد. بر اين اساس اين عامل مىتواند عَ/٪ واريانس رفاه ذهنى را تبيين كند؛ و آزمون آنوا با 99 درصد اطمينان (F= I عO/VEY) مدل را مناسب ارزيابى مى كند. وضعيت اجتماع خانواده بر رفاه ذهنى كودكان تأثير على دارد و فرض H با 99 درصد اطمينان رد شده و فرضيه تحقيق تأييد مىشود. بر اين اساس با افزايش يك انحراف معيار در مطلوبيت اجتماع خانواده ع9ع/• انحراف معيار بر رفاه ذهنى كودكان افزوده مىشود و 
جدول (7) تحليل رگرسيونى دومتغيره تأثير اجتماع خانواده بر رفاه ذهنى كودكان به تفكيك جنس

\begin{tabular}{|c|c|c|c|c|c|}
\hline$p$ & $\mathbf{F}$ & $\mathbf{R}^{2}$ Adj. & $\mathbf{R}^{2}$ & $\mathbf{R}$ & جنس \\
\hline$<\cdot / \cdots \cdot$ & ITY/TEK & - MAY & $\cdot / \pi / 0$ & $\cdot / 7 r$. & دختر \\
\hline$<\cdot / \cdots \cdot \mid$ & rO/r^A &.$/ .94$ & $.1 .9 \mathrm{~V}$ & $\cdot / \mu 11$ & يسر \\
\hline$p$ & $\mathrm{t}$ & $\beta$ & b & متغير مستقل & \\
\hline$<\cdot / \cdots+1$ & $11 / 01 \mathrm{~V}$ & $\cdot / 7 r$. & $\varepsilon / \mu T r$ & \multirow{2}{*}{ اجتماع خانو اده } & دختر \\
\hline$<\cdot / \cdots \cdot \mid$ & $0 / . r q$ &.$/ 11$ & $r / \pi / 1$ & & يسر \\
\hline
\end{tabular}

نكته قابل تأمل درباره اجتماعات مختلف كودكان اين است كه هر يك از اين اجتماعات تأثير متفاوتى بر دو جنس دختر و يسر دارند. به عبارت سادهتر تغيير اجتماع خانواده (مثبت يا منفى) دو بار بيشتر از يسران، رفاه ذهنى دختران را تحتتأثير قرار مىدهد كه نشان از اهميت خانواده براى دختران دارد.

دوستان

همجون خانواده، اجتماع دوستان نيز مىتواند اهميت به سزايى در رفاه ذهنى كودكان داشته باشد. فرضيه مطرحشده در اين اجتماع نيز همانند خانواده است. (ابه نظر مىرسد بين وضعيت اجتماع دوستان و رفاه ذهنى كودكان رابطه مستقيم وجود دارد)،. بهعبارتديخر هر جه اجتماع دوستان از وضعيت مطلوبترى برخوردار باشد، رفاه ذهنى كودكان افزايش مىيابد و برعكسش. نتايج آزمون همبستخى بيرسون وجود همبستكى ير شدتى را بين اجتماع دوستان و وضعيت رفاه ذهنى كودكان نشان مى دهد. با 99 درصد اطمينان بين اين دو رابطهاى مستقيم با شدت 091 • •برقرار است. 
The Relationship between Communities and Subjective Well-Being of Children ...

با توجه به نتيجه بالا مىتوانيم به دنبال آزمون تأثير على فرضيه مطرح در يزوهش باشيم. نتايج تحليل رگرسيون دو متغيره نشان داده است كه اجتماع دوستان عץ/ • واريانس رفاه ذهنى كودكان را تبيين مى كند.

با 99 درصد اطمينان مىتوان مدل موجود را مدلى قابلقبول توصيف كرد و بر اساس نتايج حاصل از مدل با افزايش يا كاهش ا انحراف معيار مطلوبيت در اجتماع دوستان به ميزان 1091 • انحر اف معيار رفاه ذهنى كودكان تغيير ايجاد مىشود. نتايج حاصله نشان داد كه اين تأثير مستقيم است. همانطور كه مشخص شد، اجتماع دوستان تأثير بسيار قابلتوجهى

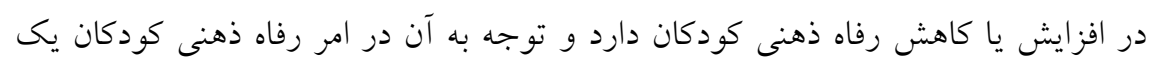
نياز اساسى است. جدول (V) تحليل رگرسيونى دومتغيره تأثير اجتماع دوستان بر رفاه ذهنى كودكان به تفكيك

\begin{tabular}{|c|c|c|c|c|c|}
\hline$p$ & $\mathbf{F}$ & $\mathbf{R}_{\text {Adj. }}^{2}$ & $\mathbf{R}^{2}$ & $\mathbf{R}$ & جنس \\
\hline$<\cdot / \cdots \cdot$ & $|\varepsilon r /| \varepsilon \varepsilon$ & $\cdot / \varepsilon \cdot$ & $\cdot / \varepsilon \cdot r$ & ס ס . & دختر \\
\hline$<\cdot \cdots \cdot \cdot \mid$ & $99 / \Lambda \cdot r$ & • r & $\cdot / 797$ & $\cdot / 0 \varepsilon \varepsilon$ & بسر \\
\hline$p$ & $\mathrm{t}$ & $\beta$ & $\mathrm{b}$ & متغير مستقل & \\
\hline$<\cdot / \cdots+$ & $11 / 97 \varepsilon$ & ס ס / . & ו ו & & دختر \\
\hline$<\cdot / \cdots+$ & $9 / 99$. & $\cdot / 0 \varepsilon \varepsilon$ & $r / r V \Lambda$ & & يسر \\
\hline
\end{tabular}


جالب است بدانيم تأثير گروه دوستان بر رفاه ذهنى دختران همجِون گروه خانواده بيشتر

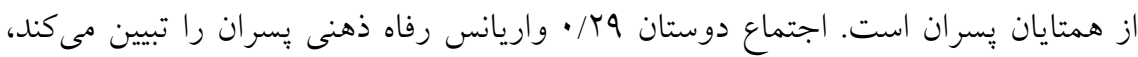

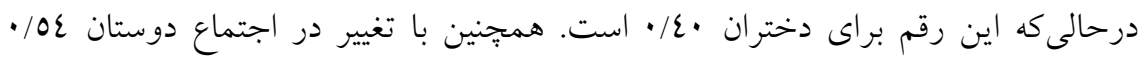
انحراف معيار در رفاه ذهنى پسران تغيير ايجاد مىشود، درحالى كه اين رقم براى دختران rآ/ • انحر اف معيار است.

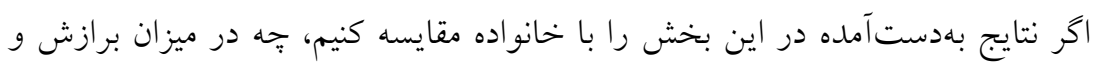

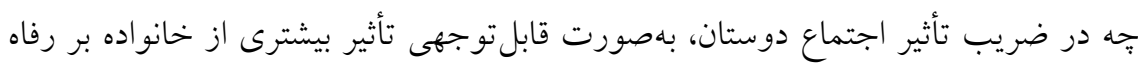
ذهنى كودكان دارد.

\section{محيط زندگى (محله) - م}

يكى ديكر از محيطهاى زندگى كودى كه كودكان ارتباط مستقيمى با آن دارند، محيط

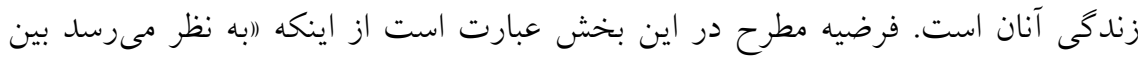

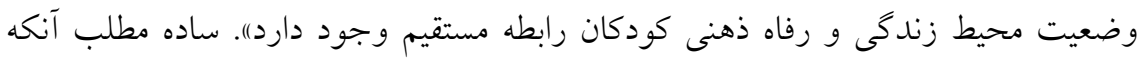
فرض مىشود هرجه محيط زندكى كودكان وضعيت مطلوبترى داشته باشد، رفاه ذهنى ردانى

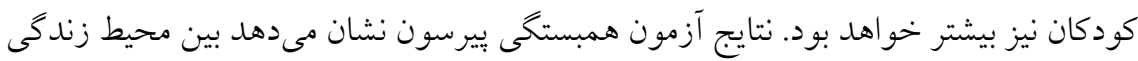

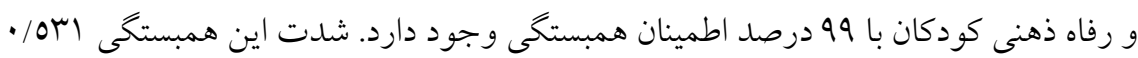
است. با توجه به نتيجه فوق مىتوان تحليل ركرسيونى دومتغيره به شيوه همزمان به ردان راد دنبال

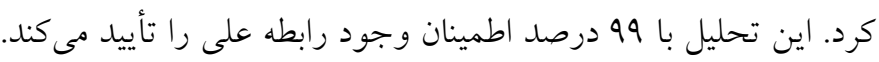

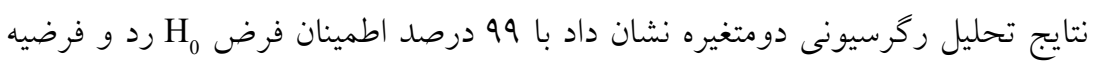
تحقيق تأييد مىشود. بهعبارتديخر محيط زندكى بر رفاه ذهنى كودكان تأثير على مستقيم

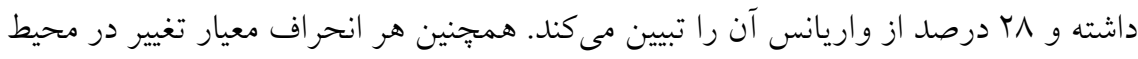
زندگى برابر البه/• انحراف معيار تغيير در رفاه ذهنى كودكان ايجاد مى كند. 
جدول (^) تحليل رگرسيونى دومتغيره تأثير محيط زندگى بر رفاه ذهنى كودكان به تفكيك جنس

\begin{tabular}{|c|c|c|c|c|c|}
\hline$p$ & $\mathbf{F}$ & $\mathbf{R}_{\text {Adj. }}^{2}$ & $\mathbf{R}^{2}$ & $\mathbf{R}$ & جنس \\
\hline$<\cdot / \cdots+$ & $95 / 170$ & $\cdot / \mu \cdot 1$ & $\cdot / \mu \cdot 0$ & . $100 r$ & دختر \\
\hline$<\cdot / \cdots \cdot$ & $\Lambda \tau /\{7)$ & $\cdot / \pi 7 \varepsilon$ & $\cdot /$ Y V & $.101 \mathrm{~V}$ & يسر \\
\hline$p$ & $\mathrm{t}$ & $\beta$ & $\mathrm{b}$ & متغير مستقل & \\
\hline$<\cdot / \cdots+$ & q/7rv & $.100 Y$ & $r / 9 \wedge r$ & \multirow{2}{*}{ محيط زندگى } & دختر \\
\hline$<\cdot / \cdots+$ & $9 / 791$ & $.101 \mathrm{~V}$ & $r / \varepsilon \mid 1$ & & يُسر \\
\hline
\end{tabular}

جالب است كه همجون دو اجتماع قبلى باز هم تأثير محيط بر رفاه ذهنى دختران بيشتر از

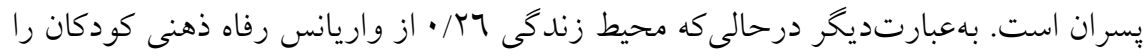
تبيين مى كند، اين رقم براى دختران برابر • ب/ • است. علاوه بر اين ضريب تأثير محيط زندگى بر رفاه ذهنى كودكان يسر 01 • • است درحالى كه اين رقم براى دختران برابر 00 • است.

\section{فضاى مدرسه}

كودكان در سنين ده تا دوازده سال حداقل ينج ساعت از طول روز را در مدارس خود

سبرى مى كنند. وضعيت مدرسه آنان بدون شك يكى از عو امل مؤثر در وضعيت رفاه ذهنى آنان محسوب مىشود. بر همين اساس مطالعات بزوهش بيشرو اين كفايت نظرى را در دست داده كه فضاى مدرسه يك عامل مؤثر در تعيين وضعيت رفاه ذهنى كودكان است. فرضيه نيز اين گونه تشريح شده است كه (به نظر مىرسد بين فضاى مدرسه و رفاه ذهنى كودكان رابطه مستقيم وجود دارد)؛؛ يعنى هرجهه وضعيت فضاى مدرسه بهتر باشد، رفاه ذهنى 
كودكان بيشتر مىشود، بديهى است كه معكوس اين قضيه نيز برقرار است. بر اساس نتيجه آزمون بيرسون بين فضاى مدرسه و رفاه ذهنى كودكان با 99 درصد اطمينان رابطه مستقيمى وجود دارد. شدت اين رابطه \&VY/ • است. بر مبناى اين ارتباط مىتوان در تحليل رگرسيونى به دنبال رابطه على بين فضاى مدرسه و رفاه ذهنى كودكان بود. اطلاعات مستخرج از تحليل ركرسيونى ارتباط على بين فضاى مدرسه و رفاه ذهنى كودكان را با 99 درصد اطمينان تأييد كرده و فرض H 0 را رد مى كند. بر اساس نتايج بهدستآمده r T/ • از واريانس رفاه ذهنى توسط محيط مدرسه تبيين مىشود. همانطور كه مشاهده مىشود با تغيير يك انحراف معيار در وضعيت فضاى مدرسه به ميزان عVT/ • انحراف معيار در رفاه ذهنى كودكان تغيير به وجود مى آيد. برخلاف سه اجتماع يا محيط قبلى تحليل تطبيقى وضعيت دختران و بسر ان تفاوتى نشان نمى دهد درواقع اختلاف ضريب برازش فضاى مدرسه براى دختران و يسران ا درصد به نفع بسران است، در رابطه با ضريب تعيين يا ضريب تأثير فضاى مدرسه نيز همين 1 • • مصداق دارد. جدول (9) تحليل رگرسيونى دومتغيره تأثير فضاى مدرسه بر رفاه ذهنى كودكان به تفكيك جنس

\begin{tabular}{|c|c|c|c|c|c|}
\hline$p$ & $\mathbf{F}$ & $\mathbf{R}^{2}{ }_{\text {Adj. }}$ & $\mathbf{R}^{2}$ & $\mathbf{R}$ & جنس \\
\hline$<\cdot / \cdots+$ & $09 / 911$ & $\cdot / Y I V$ & ./TYI & $\cdot / \varepsilon V \cdot$ & دختر \\
\hline$<\cdot / \cdots \cdot$ & $V \cdot / \wedge 7$. & . ITTV & . & $\cdot / \varepsilon \wedge$. & يِّر \\
\hline$p$ & $\mathrm{t}$ & $\beta$ & $\mathrm{b}$ & متغير مستقل & \\
\hline$<\cdot / \cdots+$ & $V / V \varepsilon O$ & $\cdot / \varepsilon V$. & $T / \nearrow \varepsilon r$ & \multirow{2}{*}{ محيط زندگى } & دختر \\
\hline$<\cdot / \cdots$, & 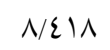 & $\cdot / \varepsilon \wedge$. & T/TO. & & يسر \\
\hline
\end{tabular}


The Relationship between Communities and Subjective Well-Being of Children ...

\section{افر اد مدرسه}

افراد درون مدرسه از دانشآموزان گرفته تا معاونان و معلمان دسته ديخرى هستند كه بعد ارتباطى مدرسه را يررنختر در نظر مى گيرد. فرض ما همانند جهار محيط قبلى مبتنى برفرض ارتباطى مثبت و مستقيم بين مطلوبيت رفتار افراد درون مدرسه با رفاه ذهنى كودكان است. فرض مورد آزمون در اين يزوهش عبارت است از اينكه (ابه نظر مىرسد بين وضعيت رفتارى افراد درون مدرسه و رفاه ذهنى كودكان رابطه مستقيم وجود دارد). به عبارت بهتر هرجهه رفتار و كنش افراد درون مدرسه بهبود يابد رفاه ذهنى كودكان نيز افزايش مىيابد. مصداق برعكس آن نيز برقرار است. نتايج آزمون همبستخى بيرسون نشان مىدها بين وضعيت رفتار درون مدرسه با رفاه ذهنى كودكان با 99 درصد اطمينان تأييد و فرض H در مورد همبستكى اين دو رد مىشود. البته شدت اين رابطه ب // است و ميزان آن نسبت به جهار گروه قبلى بسيار اندى است. با تأييد فرض بالا ادامه آزمون فرضيه خود مبنى بر ارتباط على اين دو متغير را بيخيرى مى كنيم. هر جند تحليل ركرسيونى ارتباط على وضعيت افر اد مدرسه بر رفاه ذهنى كودكان را نشان مىدهد، اما اين ارتباط بسيار ضعيف است. بر اساس نتايج مشخص است كه وضعيت افراد درون مدرسه تنها 1 •/ • از وضعيت رفاه ذهنى كودكان را تبيين مىكند. فرض H $H_{0}$ رد ورض تحقيق ما مبنى بر تأثير على افراد مدرسه بر رفاه ذهنى كودكان با 99 درصد تأييد مىشود. البته اين تأثير بسيار ناجيز و در حد تبيين تنها 1 • • از واريانس رفاه ذهنى كودكان است. علاوه بر اين ضريب تأثير اين رابطه در حد r | / است به اين معنى كه با تغيير يك انحراف معيار در وضعيت افراد مدرسه Y |/ • انحراف معيار تغيير در رفاه ذهنى كودكان شكل مى گيرد. 
جدول (• (1) تحليل رگرسيونى دومتغيره تأثير افراد مدرسه بر رفاه ذهنى كودكان به تفكيك جنس

\begin{tabular}{|c|c|c|c|c|c|}
\hline$p$ & $\mathbf{F}$ & $\mathbf{R}^{2}{ }_{\text {Adj. }}$ & $\mathbf{R}^{2}$ & $\mathbf{R}$ & جنس \\
\hline$\cdot / \cdot r V$ & $\varepsilon / 490$ & .1 .17 &.$/ \cdot r$. & $\cdot / 1 \varepsilon r$ & دختر \\
\hline$\cdot / \cdot \wedge r$ & $r / \cdot r V$ & $\cdot \cdots \wedge$ &.$/ \cdot 1 r$ &.$/ 114$ & يسر \\
\hline$p$ & $\mathrm{t}$ & $\beta$ & b & متغير مستقل & \\
\hline$\cdot / \cdot r V$ & $r / .97$ & •/ノ々 & .1077 & \multirow{2}{*}{ محيط زندگى } & دختر \\
\hline$\cdot / \cdot \wedge r$ & $1 / V \varepsilon$. &.$/ 11 Y$ & $\cdot /$ roV & & سر \\
\hline
\end{tabular}

نكته بسيار جالب در اين مقوله اين است كه اخر بخواهيم تأثير ارتباط افراد درون مدرسه را بر رفاه ذهنى كودكان در دو گروه مجزاى دختر و بسر بسنجيم، روابط افراد مدرسه با يسران تأثيرى بر رفاه ذهنى آنان ندارد.

\section{مدل تحليلى تأثير اجتماعات بر رفاه ذهنى كودكان}

تا اينجا با استفاده از تحليل ركرسيونى دومتغيره تمام فرضيات تحقيق حول اجتماعات كودى تأييد شد. در ادامه به دنبال واردكردن همه اين اجتماعات در يك مدل براى تبيين وضعيت رفاه ذهنى كودكان خواهيم يرداخت؛ و با استفاده از تحليل مسير به طرح مدل تجربى آن مىيردازيم.

براى جلو گيرى از اطاله و حشو در اين قسمت به جداول و مدلها اكتفا و توضيحات اساسى در انتها مطرح خواهد شد. فرايند عمل اينكونه است كه تمام ينج اجتماع وارد تحليلشده و سֶّ بر اساس ضريب تأثير آنان فرايند تحليل مسير تا انتها بيش خواهد رفت. 


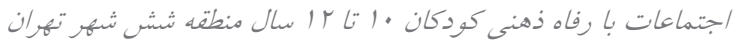

The Relationship between Communities and Subjective Well-Being of Children ...

جدول (11) تحليل رگرسيونى جند متغيره اجتماعات مؤثر بر رفاه ذهنى كودكان

\begin{tabular}{|c|c|c|c|}
\hline \multicolumn{3}{|c|}{$\mathrm{R}^{r}=\cdot / 0 \mathrm{Vq}$} & $p<\cdot / \cdots \cdot 1$ \\
\hline$p$ & $\mathrm{t}$ & $\beta$ & مدل \\
\hline$\cdot / \cdots$ & V/RT. & $\cdot / T \varepsilon r$ & فضاى مدرسه \\
\hline$\cdot / O V Y$ &.$- \cdot 1077$ & $-\cdot / \cdot 11$ & افر اد مدرسه \\
\hline$\cdot \cdots$ & $0 / \cdot 17$ & $\cdot / 1 \wedge 7$ & محيط زندگى \\
\hline$\bullet \cdots$ & $1 . / 991$ & $\cdot \pi V 7$ & كروه دوستان \\
\hline$\cdot / \cdots$ & $1 / 779$ & $\cdot \mu \cdot \mu$ & خانو اده \\
\hline
\end{tabular}

واردكردن تمام اجتماعات در مدل تحليلى نشان داده است كه در جمع، OVV • از واريانس رفاه ذهنى كودكان توسط اين ينج اجتماع قابل تبيين است؛ و همجنان گروه دوستى و خانو اده مهمترين عوامل در تعيين وضعيت رفاه ذهنى كودكان است. تأثير عوامل فضا و افراد مدرسه، محيط زندگى و خانواده بر وضعيت گروه دوستى با ضريب برازش 199/، محيط زندگى و فضاى مدرسه مهمترين عوامل هستند و تأثير عوامل فضا و افر اد مدرسه و محيط زندگى سب/ • بر وضعيت خانو اده موردبررسى قرارگرفته است. نهايتاً •^^••• از واريانس عامل فضاى مدرسه توسط عوامل افراد مدرسه و محيط زندگى قابل تبيين است. در آخرين مسير نيز مشاهده مىشود محيط زندگى ^ درصد از وضعيت فضاى مدرسه را تبيين مى كند. مدل نهايى نشان مىدهد كروه دوستان با ضريب تعيين VV/ • بيشترين تأثير مستقيم را بر رفاه ذهنى كودكان دارد و سيس خانواده با •ب/٪ يس از گروه دوستان حائز 
Social Welfare Quarterly, Vol 19, Summer 2019, No 73

اهميت است. بالينحال كل تأثير محيط زندگى بر رفاه ذهنى كودكان نشان مىدهد كه محيط زندگى با ضريب مستقيم و غيرمستقيم ^ع/• بيشترين تأثير را بر رفاه ذهنى كودكان دارد. همجنين فضاى مدرسه نيز با ضريب مستقيم و غيرمستقيم سب/ • از خانواده اهميت بيشترى مىيابد؛ بنابراين محيط زندكى در بين عوامل بيشترين تأثير را بر رفاه كودكان دارند، بسازاين

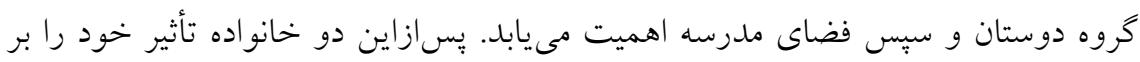
رفاه ذهنى كودكان مى گذارد. توجه به اين نكته كه تحقيق حاضر دريكى از مناطق سطح بالاى تهران انجام يذيرفته يك نكته اساسى را نشان مىدهد، بهعبارتديخر كم بودن سهم خانواده در تعيين رفاه ذهنى كودكان مىتواند از بالا بودن وضعيت اقتصادى افراد اين منطقه تأثير يذيرفته باشد.

شكل (r) مدل رگرسيونى جند متغيره عوامل مؤثر بر رفاه ذهنى و متغيرهاى ميانى

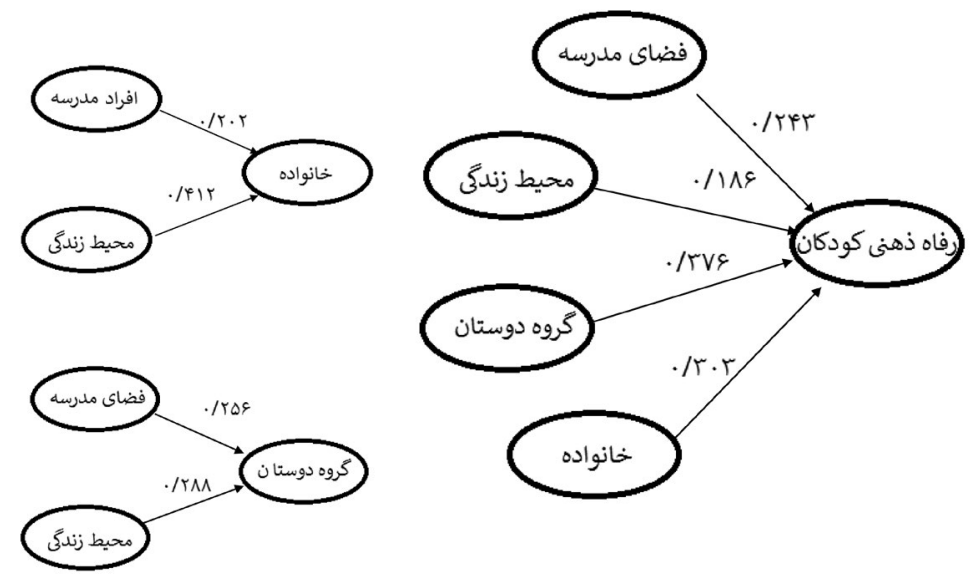


The Relationship between Communities and Subjective Well-Being of Children ...

$$
\text { شكل (ع) مدل تحليلى اجتماعات مؤثر بر رفاه ذهنى كودكان }
$$

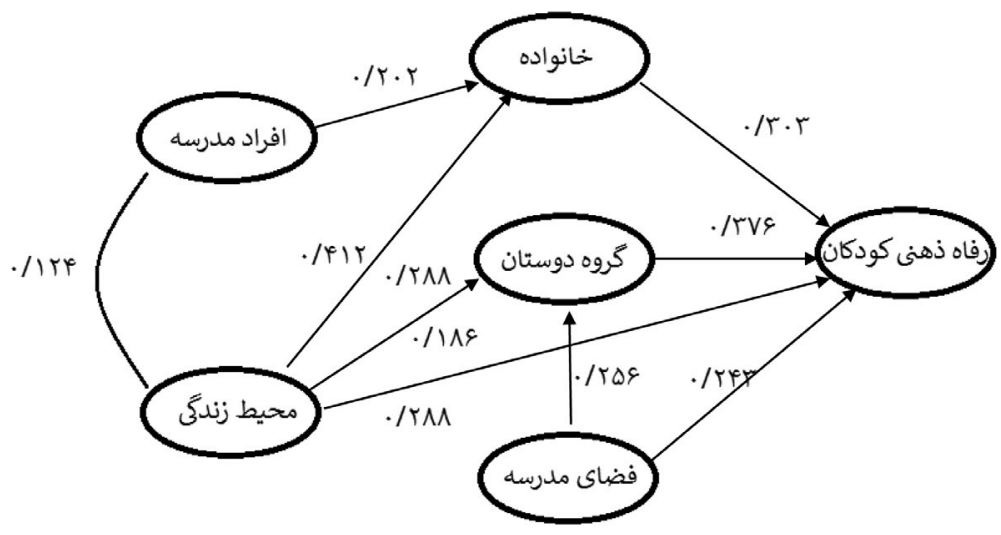

\section{بحث}

اگر جهه مفهوم رفاه ذهنى مفهومى مبهم و بيّيجيده است، با مطالعه ادبيات نظرى بيرامون

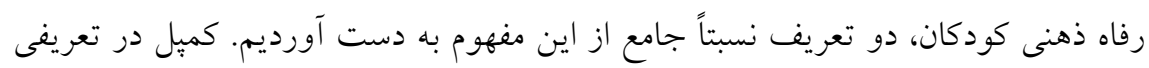
جامع و قديمى، رفاه ذهنى را بر يايه ويزگى هاى اصلى درى و ارزيابى هر فرد از تجاربش شامل احساسات مثبت، نبود احساسات منفى و رضايت از زندكى كلى تعريف مى كند (گروسمنوس و همكاران، 0 (Y). دينر با تعريفى تكميلى رفاه ذهنى را داراى دو جنبه عاطفى و شناختى معرفى مى كند كه جنبه عاطفى شامل احساسات مثبت؛ احساسات منفى و جنبه شناختى شامل رضايت از زندگى، رضايت از حوزههاى زندگى و كيفيت زندگى است

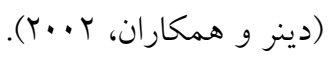

در مطالعات نظرى يزّوهش بهخوبى نشان داده شد كه توجه به رفاه ذهنى از سابقه طولانى برخوردار است، اما توجه به كودكان امرى متأخر بوده و بهتدريج نظر كودكان براى 
ارزيابى وضعيت رفاه ذهنى و شناسايى عوامل مؤثر بر آن موردتوجه قرار كرفت. كودكان

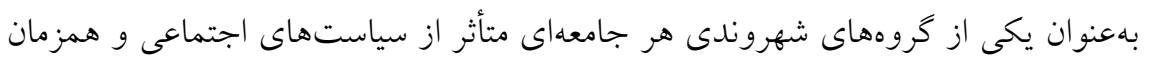

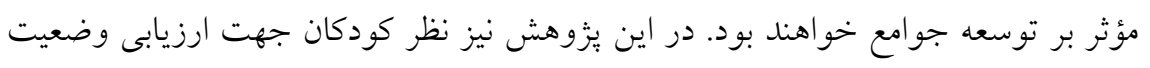
رفاه ذهنى و بررسى تأثير هر يك جوامع حضور بر حس رضايت كودكان ديده شده است.

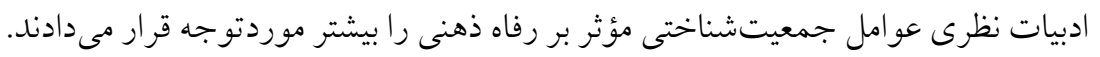

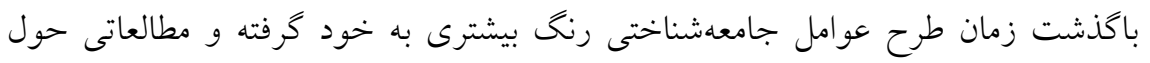

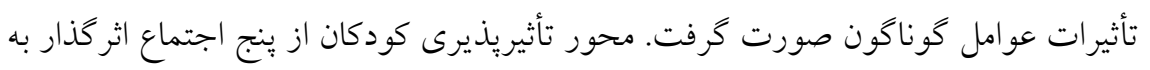

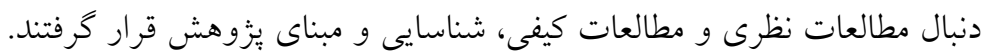

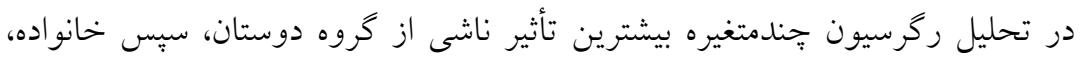

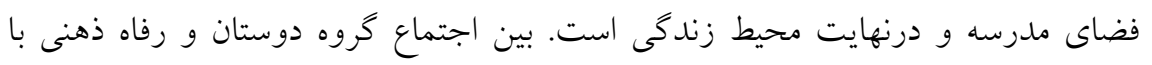

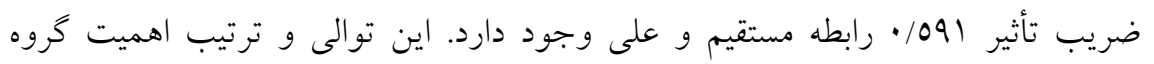
دوستان و در مواقعى اولويت بر خانواده را شفاف مى سازد. كروه دوستان بهويزه در سنين

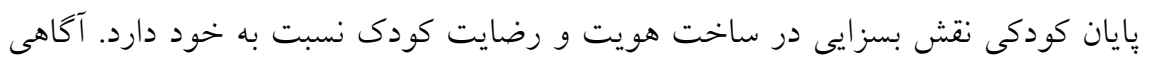

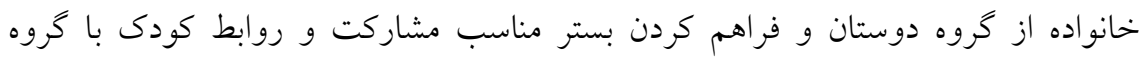

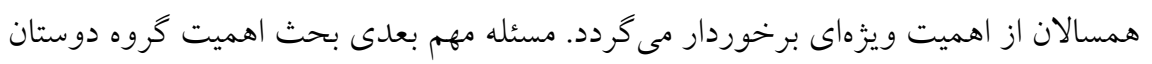

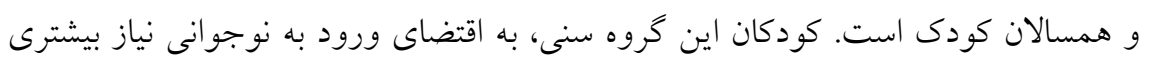

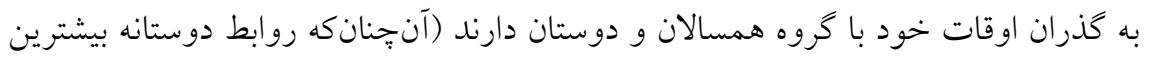

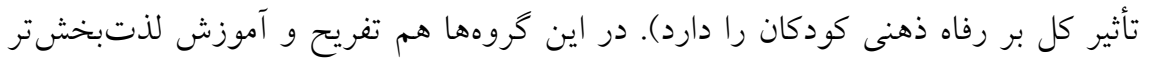

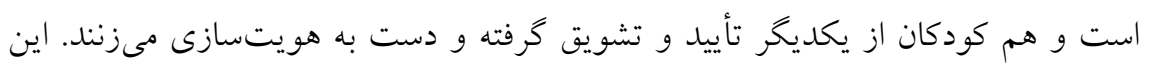

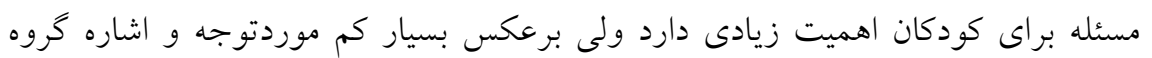

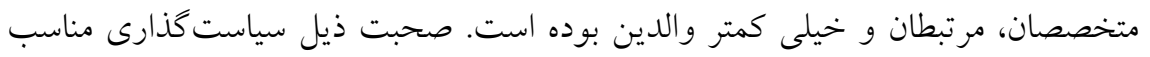
بحث دوستان، بىارتباط با ساير سياستها نيست. اينكه مسئله دوستى و روابط دوستى براى 
The Relationship between Communities and Subjective Well-Being of Children ...

كودكان مهم است بايد در آموزشهاى همخانى براى همه والدين شفاف شود و رسانهها وظيفه اين آموزش و انتقال اطلاعات را بهخوبى انجام دهند. همجنين اصلاح نظام آموزشى، در جهت بهبود روابط كودكان با يكديخر و معلمين يكى از محورهاى اصلى سياست گذارى در اين حوزه است. همجنين با توجه به اينكه اهميت بحث همسالان در مشاركت و بازى براى كودكان آشكار مىشود لازم است به مسئله فراهم كردن فضاى فراغتى و مشاركتى امن در محلهها توجه شود. اين موضوع به تقويت ارتباط كودكان كمك مى كند و تأثير زيادى بر رضايت ذهنى كودكان در شكل و سطح روابطشان با دوستان خواهد داشت. بين وضعيت محله زندگى و رفاه ذهنى با ضريب تأثير اسO • رابطه مستقيم و على وجود دارد. از ديخر نتايج جالبتوجه يزوهش اهميت فراوان كيفيت فضا و محله زندگى براى كودى است. نكتهاى كه در ابتدا داراى درجه بالايى از اهميت تصور نمىشد و بيبحيدگى اين نكته از جند دليل نشات مى گيرد. در واقع محله بخشى از عوامل گوناكون را تحت تأثير قرار مى دهد. يك محله خوب براى كودكان محلهاى با فضاى كافى طبيعى و مصنوعى براى بازى و تفريح فردى و گروهى، برخوردارى از امكانات و نيازهاى كودى و درنهايت فراهم بودن امنيت كافى براى كودكان جهت استفاده از همه موارد است. در واقع كودكان در اين سن به مرحلهاى وارد شده كه به دنبال رشد و يرورش خود به همه امكانات اعم از ورزشى، آموزشى و فراغتى نيازمند هستند. از طرف ديخر در صورت وجود امكانات وجود محيط و فضاى امن استفاده و حضور در برنامهها ركنى اساسى است. يسازاين دو خانو اده تأثير خود را بر رفاه ذهنى كودكان مى گذارد. بين مطلوبيت اجتماع خانواده و رفاه ذهنى با ضريب تأثير ع9ع/ • رابطه مستقيم و على وجود دارد. ييش از نمايان كشتن نتايج فرض بر اولويت اجتماع خانواده به ساير كروهها داشتيم. اهميت خانواده به جهت اولين اجتماع حضور كودكان و كروهى كه بيشترين زمان را با كودكان سبرى مى كنند. 
در واقع ضريب تأثير نتايج متفاوتى ارائه كرده است. اين مسئله سياست كذاران و والدين را

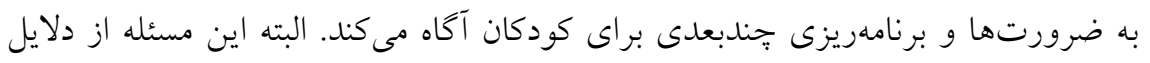

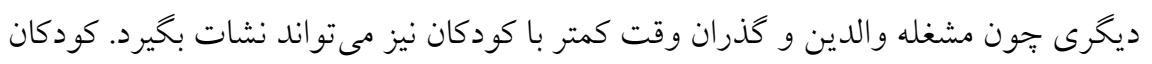

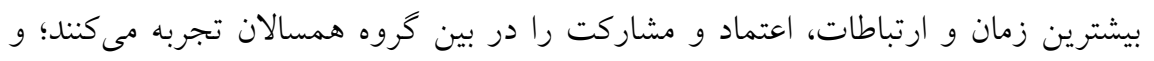

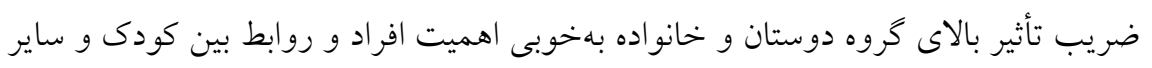

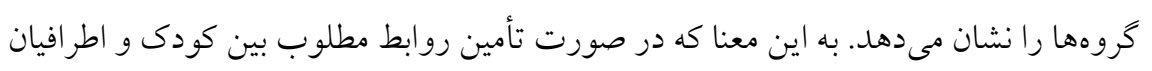

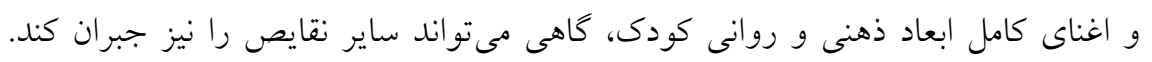

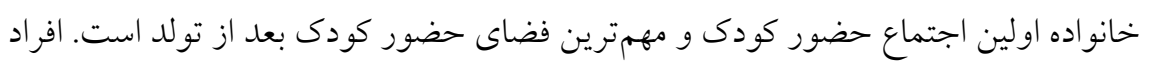

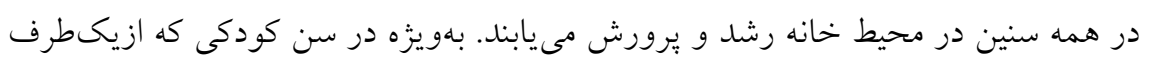

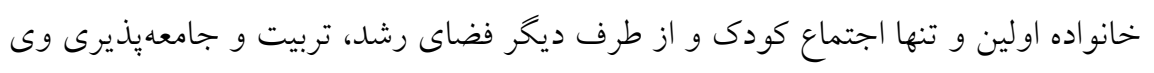

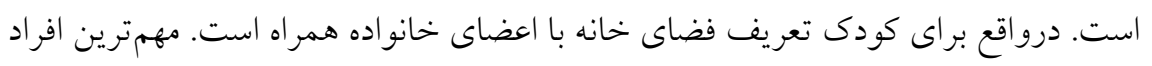

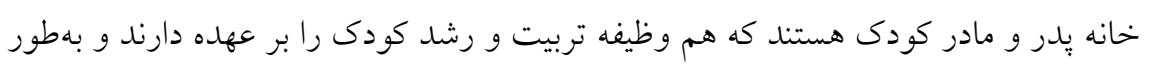

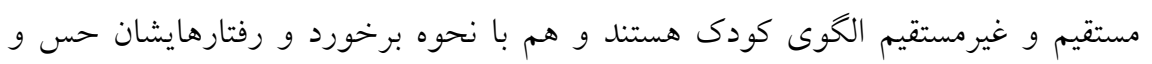

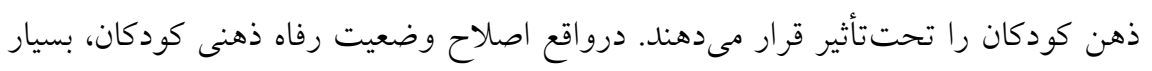

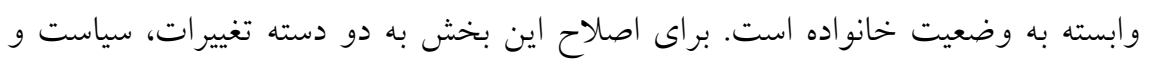

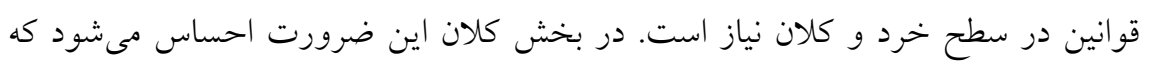

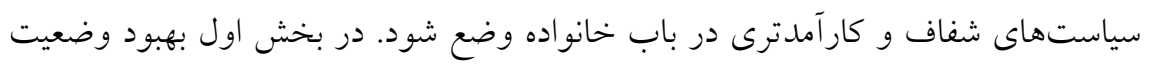

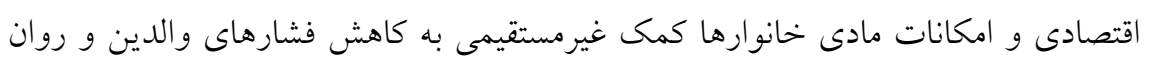

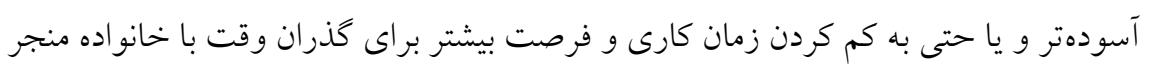

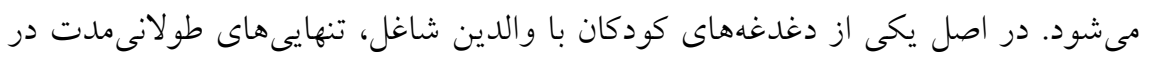

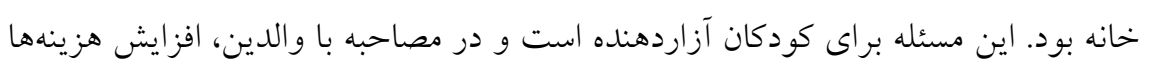

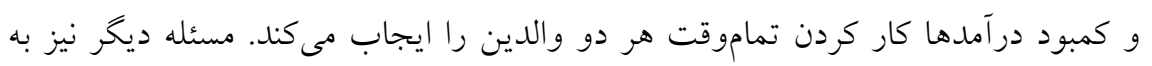


The Relationship between Communities and Subjective Well-Being of Children ...

همين موازات مطرح مىشود. فشارهاى اقتصادى روى خانواده و كار طولانىمدت، تمام توان و روان والدين را از بين برده و قادر به سبرى كردن وقت با كودى نيستند. در تعطيلات نيز يا ناجار به استراحت و رفع خستخى هفته هستند و يا دركير انجام كار عقبافتاده كه هردوى اين مسائل مانع گذران فرصت با كودى و تفريح و گردش است. اين قبيل مسائل در نمونههاى خارجى مطالعه شده نيز مطرح شده و در بزوهش حاضر نيز تأييد مىشود. حضور خانواده و كذران وقت و تفريح با كودكان رضايت كودكان نسبت به زندكى را افز ايش مى دهد.

همجنين راهكار ديخرى كه نياز به سياست گذارى كلان دارد، بركزارى دورههاى علمى تهى و آموزشى براى والدين بيش از باردارى است. دورههايى كه نه اجبارى و صورى، بلكه با فرهنگسازى مناسب همه افراد براى حضور در اين دورهها احساس نياز كنند. دورههايى كه كمك كند والدين شناخت و آكاهى درستى از احساسات، علايق و نيازهاى كودكان به دست آورند. كودكان طى رابطه درست و صميمى با والدين به احساس آرامش و امنيت در خانه دست خواهند يافت كه در منابع نظرى بحث احساس امنيت در اشكال مختلف خانه، مدرسه و محل زندكى تأثير بسزايى در رفاه ذهنى نشان خواهد داد. تغيير سياست هاى خرد هم در خانه در راستاى بهبود رفاه ذهنى كودكان نياز است. و الدين بايد بيشتر به نيازهاى كودكان توجه كنند. كودى را موردتوجه قرار دهند، از نظر اتش استفاده كنند تا نيازهاى حقيقى كودكان برآورده شود. يُزوهش به ما نشان مىدهد كه تصور و الدين درباره اينكه تصميم و انتخاب خودشان بهترين و مفيدترين تصميمات براى كودكان است،

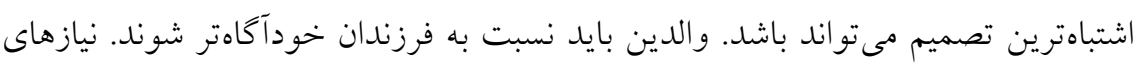
كودى را فراتر از ماديات ببينند و با مسائلى مانند حقوق كودك آشنا شوند. كنو انسيون حقوق كودى بهخوبى مسائلى در باب كودى مطرح مى كند كه اخر والدين نسبت به آنها آكاهى ييدا كنند بىشك در وضعيت رفاه ذهنى كودكان تغييرات بزركى حاصل مىشود. از قوانين 
سادهاى كه نشان مىدهد اولين حق كودى خواسته شدنش است. وقتى والدين به اين مسئله

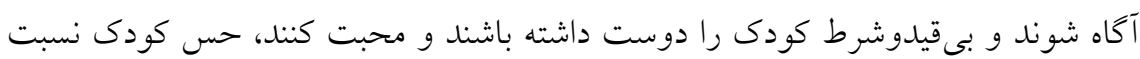

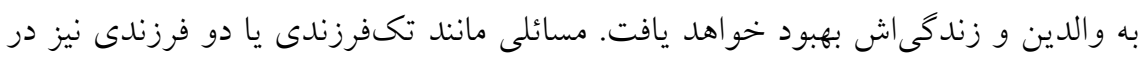

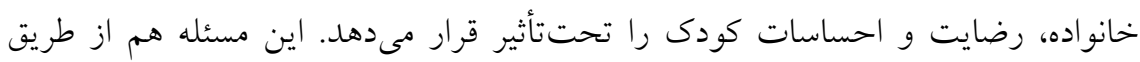

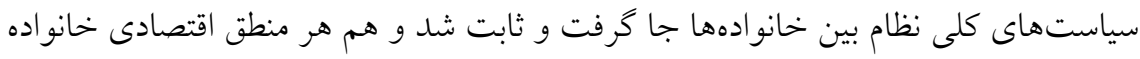

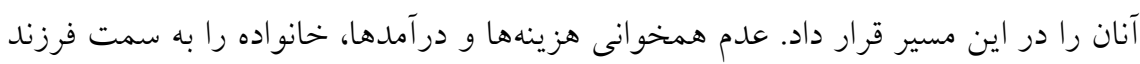

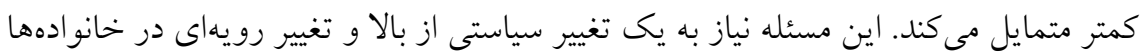

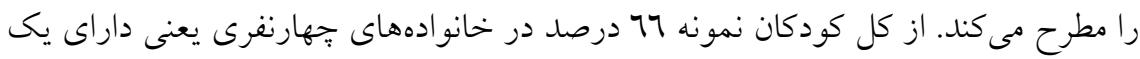

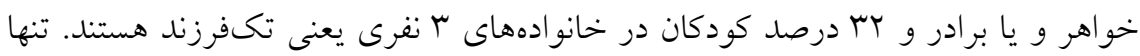

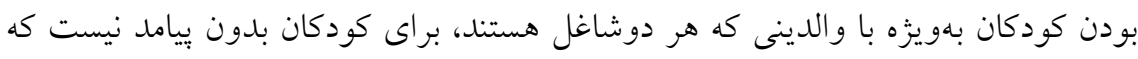

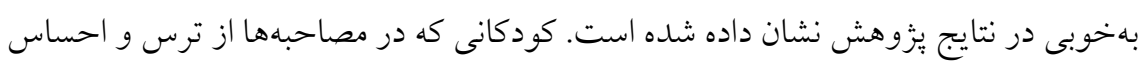
عدم امنيتهاى جدى در مواقع تنهايى صحبت مى كنند يا بهعنوان اولين خواسته به حضور

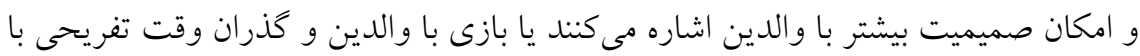
خانو اده را بهعنوان آرزو مطرح مى كنند.

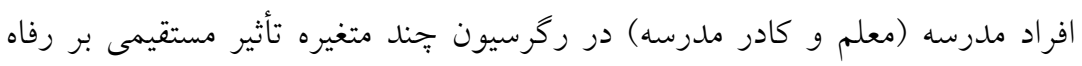

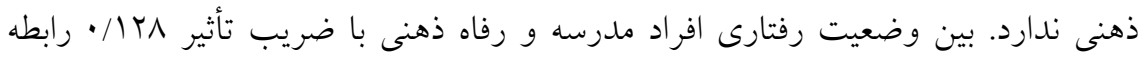

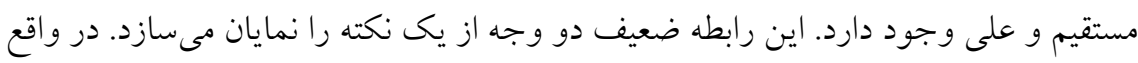

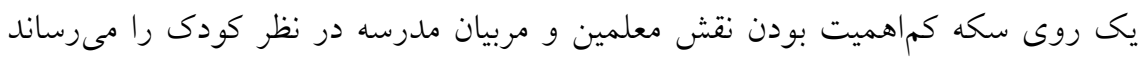

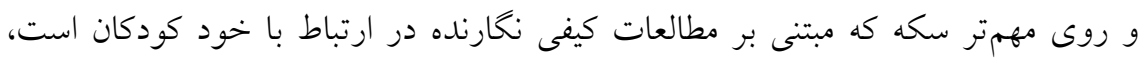

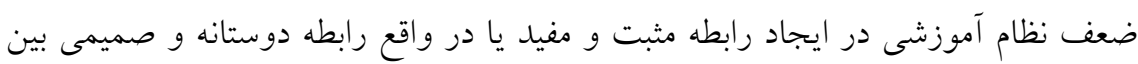

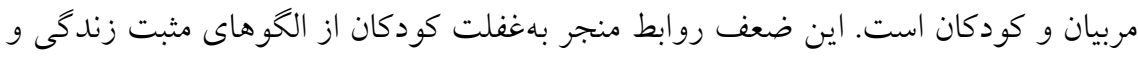

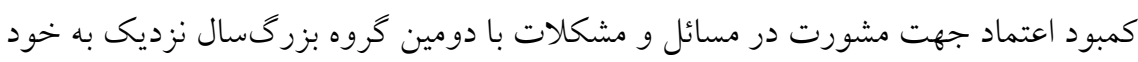


مىشود. مسئله دوم به سياستهاى آموزشى مربوط است. بحث آموزش موضوع سادهاى

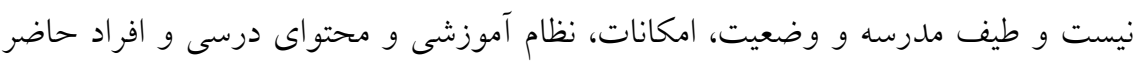

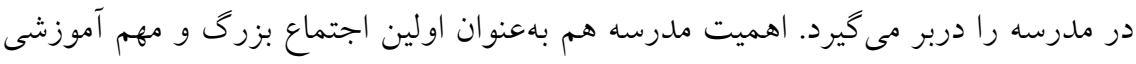

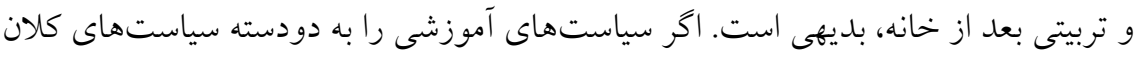

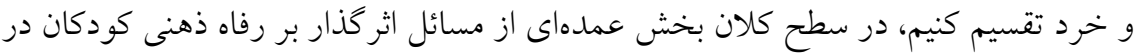

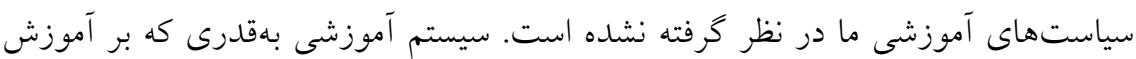

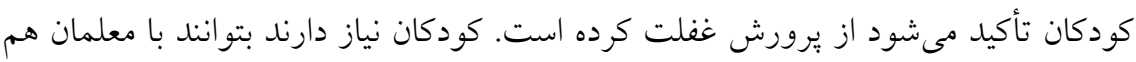
مانند والدين ارتباط برقرار كنند و نقطه اتكا و اعتماد شناخته شوند. كروهى از معلمان كه با نقان

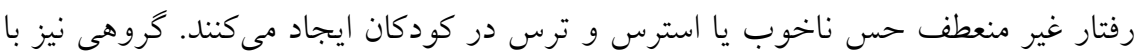

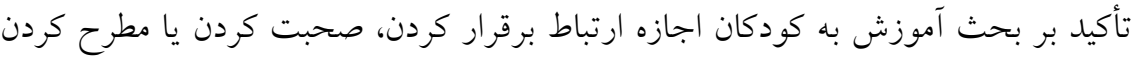

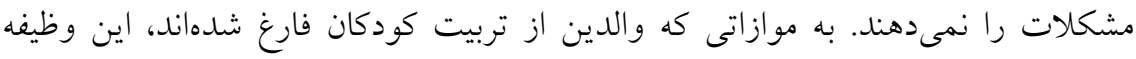
را بر عهله نظام آموزشى كذاشتهاند ولى نظام آموزشى تغييرى در روندهاى خود ايجاد

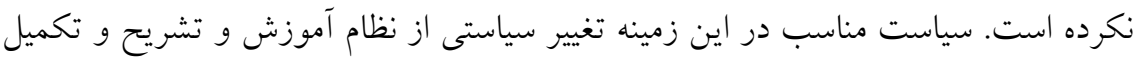

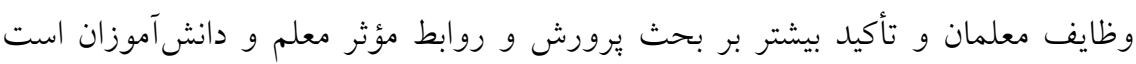

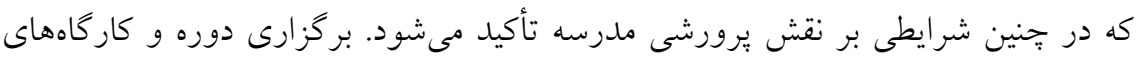

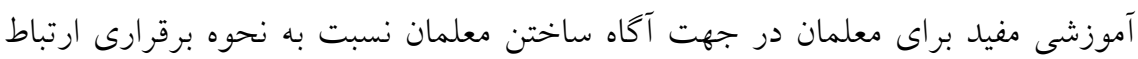

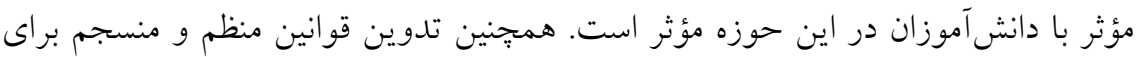

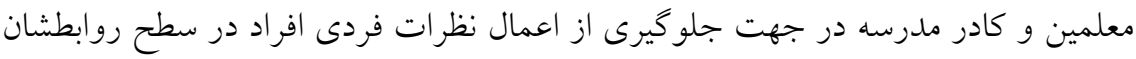
با دانش آموزان حائز اهميت است.

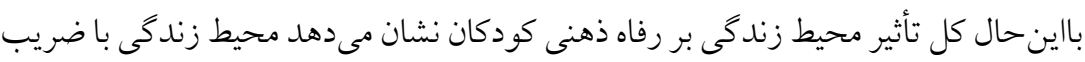

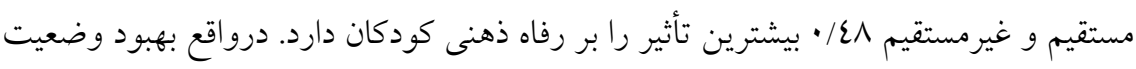
محيط زندكى مسئلهاى است كه خيلى بيشتر از نقش والدين، سياست كذاران و برنامهريزان 
شهرى نقش مؤثرى خواهند داشت. توجه به مسئله نياز كودى به مشاركتهاى جمعى و

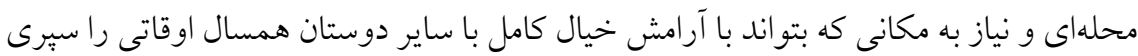

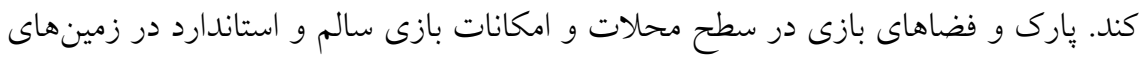
بازى بهصورت براكنده در نقاط مختلف شهر جهت رفاه حال كودكان ضرورى است. نكته ديخر در باب وضعيت محلهها كه نياز به تلاش و سياست كذارىهاى ويزٔهاى دارد، بحث امنيت است. امنيت در محله نيز يكى از مسائل بسيار مهم در محله است كه ساير موارد را نيز

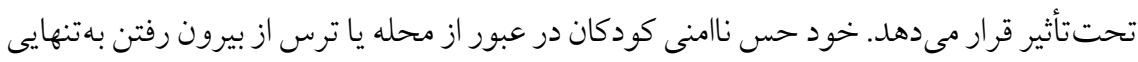

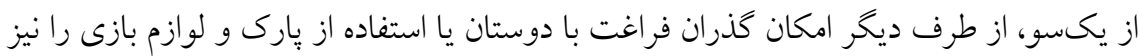

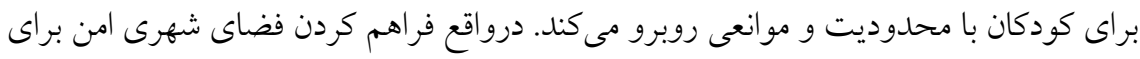

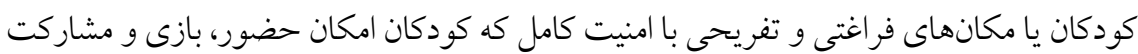

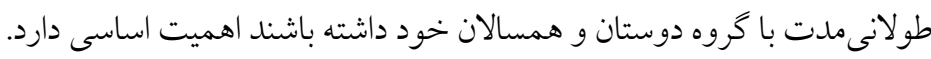

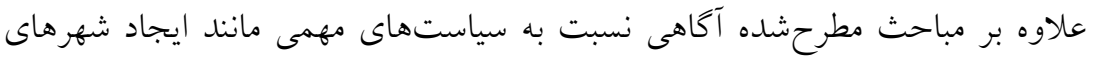
دوستدار كودى كه در سازمانهاى حمايت از كودكان در كشورهاى مختلف موردتوجه قراركرفته است، داراى اهميت است. سياست كذاران شهرى لازم است با مطالعه و تحقيقات جامع بر ايجاد اين گونه فضا و امكانات شهرى مناسب كودى تلاش بيشترى در ارتقاى رفاه عينى و ذهنى كودكان داشته باشند. بهبود وضعيت محلهها در بحث فراغت بهويزه فراغت جمعى كه هم مطلوب كودكان بهان است و هم فضا و امكان كمترى براى اين گونه فراغتها دارند مؤثر است. به بحث بحث امنيت

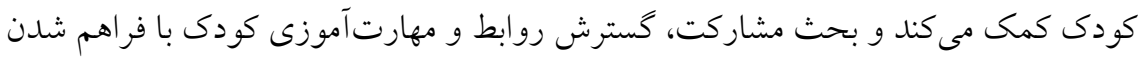
فضاى جمعى سالم و مطمئن بهبود خواهد يافت.

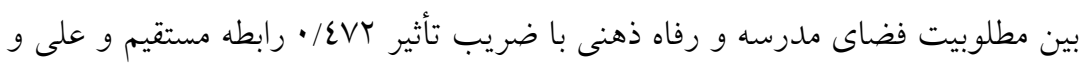
ضعيفترين رابطه وجود دارد. نتايج يزوهش نشان مىدهد كودكان نسبت به فضاى مدرسه 
The Relationship between Communities and Subjective Well-Being of Children ...

بسيار گلايهمند هستند. فقدان فضاى بازى و سرگرمى جهت اوقات فراغت و يا كمبود امكانات علمى و يكنواختى سبك آموزش منجر نارضايتى كودكان از محيط مدرسه مىشود. بهويزه كودكان آشنا به تكنولوزى و متد روز دنيا بهستتى با شرايط يكنواخت مدرسه ساز كار خواهند شد. همين نكات ريز در صورت اصلاح، تغييرات جدى و بزركى در رضايت كودكان نسبت به مدرسه و در بعد بزرگتر به زندگى ايجاد خو اهد كرد. فراهم شدن فضاى علمى از هر نظر مطلوب براى كودكان بهعنوان خانه دوم كه بيشترين كذران زمان بعد از خانه و بهويزه در كنار همسالان را به همراه دارد به تجديدنظر و سياستهاى جديد نيازمند است. علاوه بر اين نياز به يك تغيير جدى ديخر در نظام آموزشى احساس مىشود. كودكان نياز به آموزش مباحث متنوع، مطالب با حجم كمتر و مفيدترى دارند. دروسى كه اطلاعات كودكان را نسبت به امور جهان افزايش دهد. كودكان در عصرى هستند كه استفاده از ايتترنت و فضاى مجازى كسترش يافته است. بنابر اين گنجاندن محتواى درسى براى بيشخيرى از آسيبهاى احتمالى اين فضاها براهميت است. آكاهى نسبت به حقوق، آشنايى با مباحثى مانند فلسفه وجود جهان و جر ايى بديدههاو مسائلى اين جنين كمك بسيارى به كودكان خواهد كرد. از طرف ديخر شيوههاى

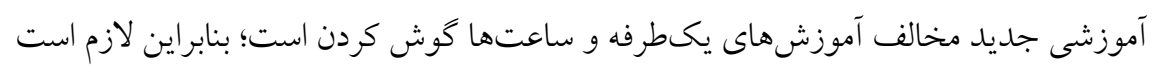
با تغيير در شيوههاى تدريس امكان آموزشهاى همراه با بازى، كارهاى گروهى و آموزشهاى جمعى را براى كودكان فراهم شود. با اين روش ضمن يادكيرى بهتر و ماندگارتر كودكان، امكان مشاركت و آموزش مهارتهاى ارتباطى صحيح نيز براى كودكان فراهم مىشود. بهويزه كودكان نسل مدنظر كه از امكان فعاليتهاى محلهاى يا گرووهاى گسترده فاميلى محروم هستند، اين آموزشهاى ضمن درس بهخوبى آنان رابراى ايفاى نقش بزرگسالى مهيا مى كند. از بحث محتوا و شيوه تدريس كه بخذريم بحث جدى تر برورش كودكان مطرح مىشود. بنابراين به نظر مىرسد مسئله رفاه ذهنى در كنار رفاه عينى داراى اهميت است و تجارب تحقيقاتى كشورهاى بيشتر توسعهيافته حاكى از همين اهميت است. توجه به نظرات و 
احساسات كودكان نسبت به واقعيت زندكى امرى جديد و بسيار سودمند است. يُّوهش به

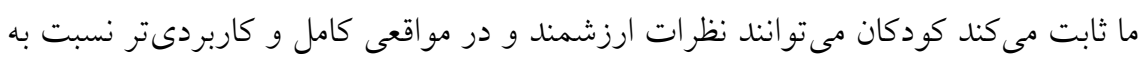

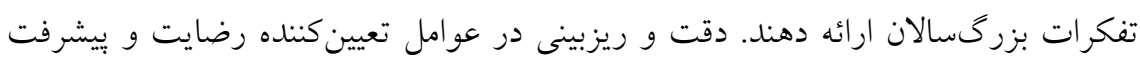
كودكان به ما كمك مى كند با تغيير و اصلاحات جزئي در سياستها و برنامههاى اجرايى

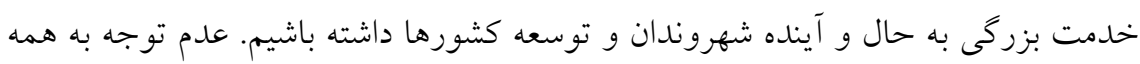

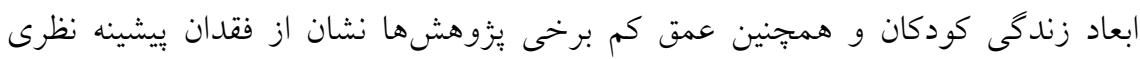
مطلوب و كافى در ايران است كه مشكل اصلى ابتداى مسير تلقى مى شود. استفاده از منابع

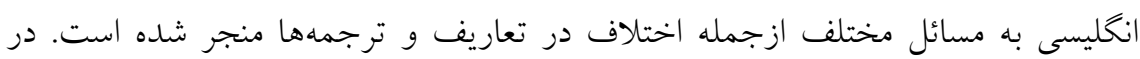
ادامه حساسيت موضوع كودكان جلب اعتماد والدين، مدرسه و آموزش يرورش را با با مشكل

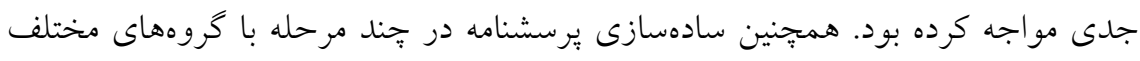
متخصصين سرعت ييشرفت كار را با مشكل مواجه كرده بود.

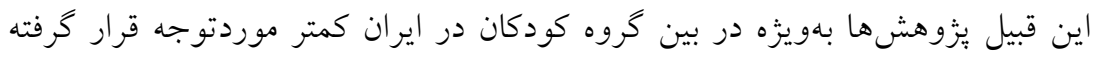

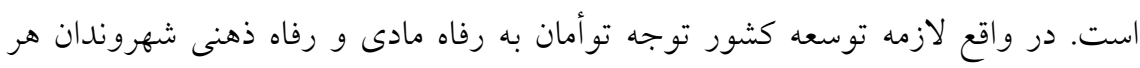

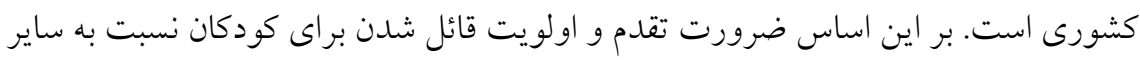

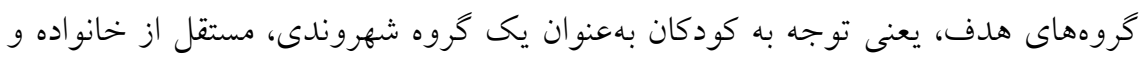

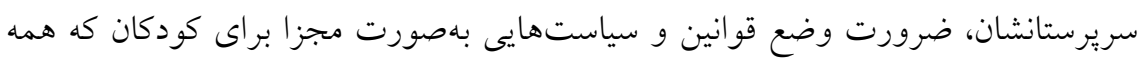

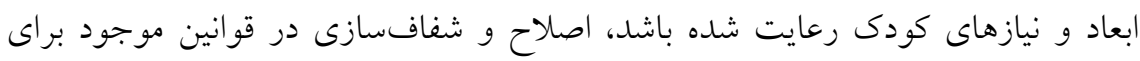

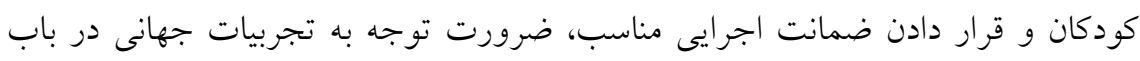

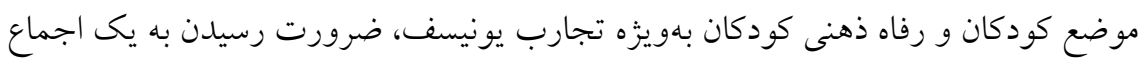
نظرى از تعريف كودى، سن كودى و نيازهاى جسمى و روانى متناسب هر سن، ضرورت بهرد وجود نهادى به مستقل و مختص امور كودكان، جهت مطالعه همه ابعاد وجودى و نيازهاى

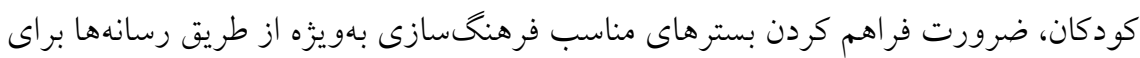


The Relationship between Communities and Subjective Well-Being of Children ...

مردم و والدين، توجه حاكميت به نقش كليدى بهبود وضعيت خانوادهها و تأثير گذارى آن بر وضعيت زندگى حال و آينده كودك، نظارت و برنامهريزى دقيقتر و علمىتر در رسانه و توليد برنامههاى مناسب و آموزنده براى كودكان، ضرورت شفاف كردن مرز وظايف و الدين

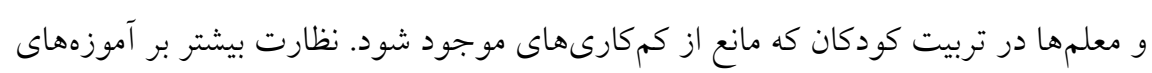
منتقلشده به كودكان در خانه، مدرسه و رسانهها و جلو كيرى از ايجاد ناهمسويى آموزهها براى كودكان، ضرورت آكاهسازى مردم نسبت به كودكان، حقوق، احساسات و نيازهايشان، ضرورت ايجاد بيوند قوى بين متخصصين اجرايى حوزه كودى و آكاهان دانشخاهى جهت همراستا شدن دانش و عمل، ضرورت بيوند بيشتر بين نهاد آموزش كودك و نهاد خانواده در راستاى كمتر شدن اختلافنظرها مهمترين بيشنهادهاى عملياتى اين مقاله است.

\section{ملاحظات اخلاقى \\ مشاركت نويسند}

همه نويسند كان در تهيه مقاله مشاركت داشتهاند.

منابع مالى

براى انتشار اين مقاله حمايت مالى مستقيم از هيج نهاد و سازمانى دريافت نشده است.

تعارض منافع

اين مقاله با ساير آثار منتشرشده از نويسندگان هميوشانى ندارد.

ييروى از اصول اخلاق يزوهش

در اين مقاله همه حقوق مرتبط با اخلاق بززوهش رعايت شده است. 
- Abari, Q., Haj Yusefi, A., Babae, h., And Rahgozar, m. (2011). Comparison of social development of children with and without children in rural areas. Social Welfare Quarterly, 11 (41), 363-343. (in Persian)

- Aghapur, M. And Aghdasi, A. (2010) The Relationship between Marital Conflict and Emotional Pathological Symptoms of Child. Women's and Family Studies, 3 (9), 27-35.(in Persian)

- Alcock, P. and Rawlinson, K. May, M. (2012). Social Policy Reference Book (Translated by A. Taj Mazniani and M. Qasemi). Tehran: Imam Sadegh University Press .(in Persian)

- Ali Tien, M.P. (2012). The Impact of School Discipline on Students' Subjective Well-Being: A Case Study of Public and Nonprofit High Schools in Area One, Tehran, 2012-2012. Unpublished M.Sc., Faculty of Social Sciences, University of Tehran, Tehran. (in Persian)

- Bradshaw, J., Keung, A., Rees, G., \& Goswami, H. (2011). Children's subjective well-being: International comparative perspectives. Children and Youth Services Review, 33(4), 548-556.

- Carrasco, M., Casas, F., Malo, S., Viñas, F., \& Dinisman, T. (2017). Changes with age in subjective well-being through the adolescent years: Differences by gender. Journal of Happiness Studies, 18(1), 63-88.

- Casas, F., \& Rees, G. (2015). Measures of children's subjective wellbeing: Analysis of the potential for cross-national comparisons. Child Indicators Research, 8(1), 49-69.

- Diener, E., Lucas, R. E., \& Oishi, S. (2002). Subjective well-being: The science of happiness and life satisfaction. In C.R. Snyder, \& S.J. Lopez (Eds.), Handbook of positive psychology (pp. 63-73). Oxford: Oxford University Press.

- Diener, E., Lucas, R. E., \& Oishi, S. (2005). Subjective well-being: The science of happiness and life satisfaction. In C. R. Snyder \& S. J. Lopez (Eds.), Handbook of positive psychology (2nd ed., pp. 63-73). New York: Oxford University Press.

- Dinisman, T., \& Ben-Arieh, A. (2016). The characteristics of children's subjective well-being. Social Indicators Research, 126(2), 555-569.

- Farahani, M. And Shukri, A. Gravand, MS And Daneshpour, Z. (2008). Individual differences in academic stress and subjective well-being: The role of coping styles. Journal of Behavioral Sciences, 2 (4), 297-304. (in Persian) 
- Fitz Patrick, T. (2004). New Theories of Welfare (translated by H. Homayounpour). Tehran: Higher Social Security Research Institute Publications. (in Persian)

- Ghaffari, etc., Karimi, AS. R., And Nozari, h. (2012). The Process of Studying the Quality of Life in Iran. Journal of Social Studies and Research, 1 (1), 2-1. (in Persian)

- Goswami, H., (2011). Social Relationships and Children's Subjective Well-Being. Soc Indic Res (2012) 107:575-588. DOI 10.1007/s11205011-9864-Z

- Goswami, H., (2013). Children's Subjective Well-being: Socio-demographic, Characteristics and Personality. Child Ind Res (2013). DOI 10.1007/s12187-013-9205-7

- Gross-Manos, D., Shimoni, E., \& Ben-Arieh, A. (2015). Subjective well-being measures tested with 12-year-olds in Israel. Child Indicators Research, 8(1), 71-92.

- Lavasani, Gh. Agiea, M. And Mohammadi Masiri, F. (2013). The relationship between meaning of life and optimism with subjective wellbeing. Journal of Psychology, 17 (1), 4-17. (in Persian)

- Main, G. (2014). Child poverty and children's subjective well-being. Child Indicators Research, 7(3), 451-472.

- Main, G. (2014). Child Poverty and Children's Subjective Well-Being. Child Ind Res (2014)

- Majedi, h. Rezai, M. And Mansouri, AS. (2014). Cognitive Interpretation of Neighborhood Public Spaces from the Identity Case Study: Nazi Abad and Mehran Neighborhood. Iranian Cultural Research Quarterly, 7 (4), 61-39. (in Persian)

- Neil, F. And Babazadeh Khorasani, b. (2012) Identifying Factors Affecting Subjective Well-Being in Iran. Monetary-Banking Research, Sixth Year, 14- 27-48(in Persian)

- Rees, G., Goswami, H., \& Bradshaw, J. (2010). Developing an index of children's subjective well-being in England: Children's Society

- Sarikhani, n. And Homaye, L. (2014). Factors Affecting Social Adjustment of Migrants (Case Study: Boomtown). Iranian Journal of Sociological Studies, 4 (13), 67-83. (in Persian)

- Shiani, M. (2003). Children's social participation. Social Welfare Quarterly, 2 (7), 15-28. (in Persian) 
- Shiani, M. And Zare, h. (2012). The impact of community-based programs on elderly mental well-being., Journal of Aging, 8 (29): 1-6. (in Persian)

- Tehran City Education Organization (2015). Statistical Yearbook of Tehran Education in 2015-2014(in Persian) 